Sławomir Lucjan Szczesio

Uniwersytet Łódzki

iD ORCID: 0000-0003-4942-8182
OBLICZA WOJNY

TOM 4 - MIASTO I WOJNA

ŁÓDŹ2021 • ISBN 978-83-8220-617-3 •s.393-426

https://doi.org/10.18778/8220-617-3.19

\title{
ŻYCIE CODZIENNE W OBLĘŻONYM SARAJEWIE (1992-1995)
}

\begin{abstract}
Streszczenie. Sarajewo - stolica Bośni i Hercegowiny - czasami jest nazywana europejską Jerozolimą. Przez kilka wieków miasto było wieloetniczną społecznością z tradycjami różnorodności i tolerancji religijnej, pomiędzy Wschodem a Zachodem. Bośniaccy Muzułmanie, Serbowie, Chorwaci i inne narody żyli obok siebie w pokoju. W przededniu wojny, w 1992 r., około $50 \%$ ludności miasta stanowili nie-Muzułmanie, wiele małżeństw było zaś mieszanych pod względem religijnym i etnicznym.
\end{abstract}

Po referendum w sprawie niepodległości Bośni i Hercegowiny przedstawiciele trzech głównych narodów tej republiki nie mogli dojść do porozumienia w sprawie przyszłości. W kwietniu 1992 r. napięcia przerodziły się w krwawą wojnę. Sarajewo stało się symbolem konfliktu etnicznego oraz interwencji humanitarnej. Miasto zostało podzielone na dwie części. Duża część Sarajewa, kontrolowana przez rząd Bośni i Hercegowiny, była oblegana przez Armię Republiki Serbskiej.

Podczas trwającego trzy i pół roku oblężenia bośniackiej stolicy cywile byli atakowani przez snajperów i pociski artyleryjskie, gdy przebywali w swoich domach, kupowali żywność na targowiskach, poszukiwali wody i spacerowali ulicą. To było jak rosyjska ruletka. Niedobory żywności i wody stały się częścią codziennego życia w Sarajewie. Dostawy prądu i gazu były nieregularne. Most powietrzny i pomoc humanitarna (głównie z UNHCR) pomogły uchronić miasto przed głodem. Pomimo miesięcy oblężenia, tysięcy zabitych cywilów, radykalnie zmienionego życia, mieszkańcy Sarajewa nie godzili się na poddanie agresorom.

Słowa kluczowe: rozpad Jugosławii, wojna w Bośni i Hercegowinie, Sarajewo, oblężenie Sarajewa, życie codzienne 
Sarajewo, stolica Bośni i Hercegowiny (BiH), nazywane europejską Jerozolimą, zostało założone w XV w. ${ }^{1}$ To w tym mieście przez setki lat mieszkali obok siebie wyznawcy czterech wielkich religii - katolicyzmu, prawosławia, islamu oraz judaizmu. Jak zauważyli autorzy jednego z przewodników po Bałkanach:

Gdy szuka się w Europie miejsca, gdzie spotykają się drogi Wschodu i Zachodu, a różne kultury przenikają się wzajemnie i odciskają swoje piętno, z pewnością dotrze się do Sarajewa. Ma ono nie tylko długą i interesującą historię, ale jest także pięknie położone wśród szczytów i wzgórz (...). Tutaj jak w soczewce kumuluje się wiele kultur ${ }^{2}$.

Tu stykały się więc różne światy i cywilizacje: Europy i Orientu. Jak stwierdziła Agnieszka Gucka: „Miasto to przez stulecia stanowiło żywy dowód, iż różnorodne grupy etniczne, nacje i kultury są w stanie pokojowo współistnieć, tworząc harmonijne, wieloetniczne i wielowyznaniowe społeczeństwo"3.

Sarajewo znajduje się w centrum Bośni i Hercegowiny, a przez jego środek przepływa rzeka Miljacka. O bośniackiej stolicy trzy razy stało się głośno w Europie i na świecie w XX w., za sprawą: zamachu na arcyksięcia Franciszka Ferdynanda i jego śmierci w 1914 r., XIV Zimowych Igrzysk Olimpijskich w 1984 r. oraz oblężenia miasta w czasie wojny w latach 1992-1995. Niektórzy nawet uważają, że w Sarajewie minione stulecie miało symbolicznie swój początek i koniec.

Stolica Bośni i Hercegowiny - jednej z sześciu republik federacji Słowian południowych - stała się po II wojnie światowej symbolem nowego socjalistycznego porządku, wprowadzanego przez Josipa Broz-Titę ${ }^{4}$. Była bowiem, jak słusznie zauważyła A. Gucka:

sztandarowym przykładem bratstva i jedinstva (jedności i braterstwa), wzorem dla reszty Bośni i pozostałych republik związkowych, jak powinno wyglądać ponadklasowe, ponadnarodowe i ponadwyznaniowe społeczeństwo. (...) Miasto staje się

${ }^{1}$ Więcej o historii Sarajewa, vide: R.J. Donia, Sarajevo: biografija grada, Sarajevo 2006; A. Gucka, Wieloetniczność Sarajewa - rys historyczny, [w:] Batkany Zachodnie między przesztościa a przysztością, red. P. ChMielewski i S.L. Szczesio, Łódź 2013, s. 369-380; D. WARszawski [K. Gebert], Sarajewo, „Krasnogruda” 1997, nr 6, s. 102-111.

2 Batkany. Bośnia i Hercegowina, Serbia, Kosowo, Macedonia, Albania. Przewodnik, Kraków 2009, s. 57-58.

3 A. Gucka, op. cit., s. 369.

${ }^{4} \mathrm{O}$ roli BiH w tzw. drugiej Jugosławii, vide: D. Wy branowski, Między niepodlegtościa a dezintegracją. Bośnia i Hercegowina w XX i XXI wieku, Szczecin 2011, s. 80-115; R.J. DonIA, op. cit., s. $230-281$. 
nowoczesną, półmilionową metropolią, jednym z najważniejszych ośrodków naukowych i kulturalnych całego regionus .

Według spisu ludności z kwietnia 1991 r. Sarajewo liczyło ponad 527000 mieszkańców, z których blisko 100000 zamieszkiwało przedmieścia i obrzeża (np. Pale, Vogošća, Ilijaš, Hadžići i Trnovo). Największą część sarajewian stanowili wówczas Muzułmanie (Boszniacy) ${ }^{6}$ - ponad 259000 (49,23\%), Serbowie - ponad 157000 (29,82\%), Jugosłowianie - ponad 56000 (10,71\%), oraz Chorwaci - ponad $34000(6,62 \%)^{7}$. Warto zwrócić uwagę na wysoki odsetek osób określających się jako Jugosłowianie, a także wiele mieszanych małżeństw ${ }^{8}$. Przez lata wydawało się, że przedstawiciele różnych narodów mogą żyć obok siebie i nic tego nie zmieni. Już w czasie wojny dziennikarka i pisarka z Sarajewa, Marina Trumić, powiedziała w wywiadzie:

My nie mieszkaliśmy obok siebie, ale razem - Serbowie, Chorwaci, Muzułmanie, Żydzi, Cyganie. Mieszkaliśmy razem, żeniliśmy się między sobą. Mój syn zawsze się śmieje, że każde małżeństwo jest mieszane, bo przecież chodzi o kobietę i mężczyznę. Ale np. ja jestem Chorwatką, mój mąż jest Serbem, a nasz syn Srdjan - nie wiem, kim on jest. Kiedyś mówił o sobie - Jugosłowianin, a teraz...?

Mieszany charakter wielu małżeństw stawał się często wielkim problemem dla tysięcy sarajewian, którzy w czasie oblężenia miasta musieli podejmować trudne wybory, dotyczące przyszłości ich wieloetnicznych rodzin.

5 A. GuCKa, op. cit., s. 377.

${ }^{6}$ Muzułmanie bośniaccy byli uznawani w socjalistycznym państwie za osobny naród, a w 1993 r. podjęto decyzję, by przedstawiciela tej narodowości nazywać: Bošnjak (Boszniak). Więcej o kwestii nazewnictwa: K. KRYSIENIEL, W cieniu Dayton. Bośnia i Hercegowina między etnokracją i demokracja konsocjonalna, Warszawa 2012, s. 19.

7 Sarajevo u periodu 1945.-1991. godina, https://www.sarajevo.ba/en/article/1222/sarajevo-u-periodu-1945-1991-godina (dostęp: 12 II 2021); R.J. Donia, op. cit., s. 293; Prosecutor v. Radovan Karadžic. Public Redacted Version OfJudgement Issued on 24 March 2016, Case No.: IT-95-5/18-T, International Tribunal for the Prosecution of Persons Responsible for Serious Violations of International Humanitarian Law Committed in the Territory of the former Yugoslavia since 1991, s. 1332, https://www.icty.org/x/cases/karadzic/tjug/en/160324_judgement.pdf (dostęp: 20 I 2021).

${ }^{8}$ Miały one stanowić, według Konstantego Geberta, nawet 45\% sarajewian. D. WARSZAwsKI, [K. GeberT], op. cit., s. 106. Barbara Demick pisze, że była to mniej więcej 1/3 wszystkich małżeństw w Sarajewie. B. Deмick, W oblężeniu. Życie pod ostrzatem na sarajewskiej ulicy, Wołowiec 2014, s. 32.

9 Rozstrzelane z wielu stron, „Gazeta Wyborcza”, 28 XII 1994, http://www.archiwum.wyborcza.pl/ (dalej: AW; dostęp: 10 II 2021). 
Przełom lat osiemdziesiątych i dziewięćdziesiątych XX w. to narastający kryzys wewnętrzny w Jugosławii i stopniowy demontaż federacji ${ }^{10}$. W czerwcu 1991 r. Lublana i Zagrzeb ogłosiły niepodległość, co oznaczało de facto rozpad wielonarodowego państwa. Rozpoczęła się tzw. wojna dziesięciodniowa w Słowenii, a także konflikt zbrojny w Chorwacji. W ich cieniu został zainicjowany marsz ku wojnie w Bośni i Hercegowinie, zwanej z powodu wieloetnicznego składu „Jugosławią w miniaturze"11. W referendum w sprawie suwerenności tej republiki, które odbyło się na przełomie lutego i marca 1992 r., stanowiący większość bośniaccy Muzułmanie i Chorwaci, przy bojkocie ludności serbskiej, opowiedzieli się za niepodległością ${ }^{12}$. W tym czasie było widać pogłębiające się podziały, gdy bośniaccy Serbowie i Chorwaci zaczęli tworzyć własne struktury quasi-państwowe (autonomiczne regiony), działające niezależnie od władz w Sarajewie. Egzemplifikacją tych działań jest ogłoszenie w styczniu 1992 r. powstania Serbskiej Republiki BiH, której "stolicą" stało się Pale koło Sarajewa (wkrótce centrum polityczne i wojskowe Serbów bośniackich). Pomimo rozmów pomiędzy przedstawicielami trzech głównych narodów nie udało się osiągnąć porozumienia. Równocześnie państwa zachodnie dążyły do uznania suwerenności kolejnej republiki jugosłowiańskiej, licząc - naiwnie - na to, że takie działania powstrzymają rozlew krwi. Niestety na początku kwietnia 1992 r. rozpoczęła się krwawa wojna, trwająca ponad trzy i pół roku, w wyniku której zginęło około 100000 osób. W wojnie tej walczyli „wszyscy ze wszystkimi”'13 a symbolem bośniackiej odsłony konfliktów jugosłowiańskich lat dziewięćdziesiątych XX w. stało się oblężenie Sarajewa.

10 Vide: M.J. Zacharias, Komunizm, federacja, nacjonalizmy. System wtadzy w Jugostawii 1943-1991. Powstanie, przeksztatcenia, rozktad, Warszawa 2004, s. 397 i nast.

${ }_{11}$ Więcej o sytuacji w $\mathrm{BiH}$ przed wybuchem wojny, vide: Bosna $i$ Hercegovina u vreme raspada SFRJ 1990-1992. Tematska zbirka dokumenata, prir. K. Nikolić, Beograd 2011; I. LučIć, Bosna i Hercegovina od prvih izbora do medunarodnog priznanja, „Časopis za suvremenu povijest” 2008, br. 1, s. 107-140; S.L. Szczesio, Droga ku wojnie - sytuacja w Bośni i Hercegowinie w latach 19901992, [w:] Batkany w XX i XXI wieku. Historia-polityka-kultura. Materiaty z konferencji "Poznać Batkany”. Toruń, 29 maja 2009 roku, red. H. STYs, S. SocH ACKI, Toruń 2009, s. 23-40.

12 O. Ibrahimagić, Državno-pravni razvitak Bosne i Hercegovine = Constitutional development of Bosnia and Hercegovina, Sarajevo 1998, s. 45, 107.

${ }_{13}$ Więcej o wojnie w BiH, vide: Balkan Battlegrounds: A Military History of the Yugoslav Confict, 1990-1995, vol. 1, Washington 2002, s. 134 i nast. 
Wspólnota Europejska uznała niepodległość Bośni i Hercegowiny 6 kwietnia 1992 r., a dzień później uczyniły to Stany Zjednoczone ${ }^{14}$. Ta data była symboliczna dla narodów Jugosławii oraz $\mathrm{BiH}$, gdyż w 1941 r. rozpoczęła się agresja państw Osi, a z kolei 6 kwietnia 1945 r. Sarajewo zostało wyzwolone przez oddziały Tity. Dzień 6 kwietnia 1992 r. jest uznany w części literatury przedmiotu za oficjalny początek wojny w Bośni i Hercegowinie, a także ostrzału i oblężenia Sarajewa ${ }^{15}$.

Strona serbska, a dokładnie utworzona formalnie w maju 1992 r. Armia Republiki Serbskiej (Vojska Republike Srpske, VRS), dowodzona przez gen. Ratko Mladicia, w krótkim czasie opanowała około $70 \%$ terytorium państwa ${ }^{16}$. Chociaż władze w Sarajewie nie kontrolowały większości obszaru BiH, to jednak były dla przedstawicieli społeczności międzynarodowej reprezentantami państwa bośniackiego.

W momencie rozpoczęcia wojny w stolicy "Jugosławii w miniaturze” znajdowała się kwatera główna Sił Ochronnych Organizacji Narodów Zjednoczonych (United Nations Protection Force, UNPROFOR). Oddziały tzw. błękitnych hełmów w pierwszej połowie $1992 \mathrm{r}$. były rozmieszczane w sąsiedniej Chorwacji, by rozdzielić siły chorwackie i serbskie, wspierane przez Jugosłowiańską Armię Ludową (Jugoslovenska narodna armija, JNA). Przedstawiciele UNPROFOR, rozlokowani w kwaterze głównej w Sarajewie, obserwowali z niepokojem pogarszającą się sytuację w mieście i republice. Wkrótce kontyngent sił pokojowych został znacznie powiększony i odgrywał istotną rolę, zapewniając dostawy pomocy humanitarnej dla tysięcy sarajewian i próbując ich ochronicíc ${ }^{17}$.

14 K.I. Begić, Bosna i Hercegovina. Od Vanceove misije do Daytonskog sporazuma (1991. - 1996.), Sarajevo 1997, s. 43-44; I. Lučić, Uzroci rata. Bosna i Hercegovina od 1980. do 1992. godine, Zagreb 2013, s. 369.

15 Vide: T. RAwski, Boszniacki nacjonalizim. Strategia budowania narodu po 1995 r., Warszawa 2019, s. 79, 164-165; M. KorzeniewskA-WiszniewskA, Serbia pod rządami Slobodana Miloševicia. Serbska polityka wobec rozpadu Jugostawii w latach dziewięćdziesiątych XX wieku, Kraków 2008, s. 138; War in the Balkans. An Encyclopedic History from the Fall of the Ottoman Empire to the Breakup of Yugoslavia, ed. R.C. Hall, Santa Barbara 2014, s. 265; A. Izetbegović, Inescapable Questions. Autobiographical Notes, Leicester 2003, s. 128.

16 M.A. HoAre, Wojna jugostowiańska, [w:] Polityka Europy Środkowej i Potudniowo-Wschodniejpo 1989 roku, red. S.P. RAMET, Warszawa 2012, s. 154.

17 Więcej o roli błękitnych hełmów w Sarajewie oraz w BiH, vide: S.L. Szczesio, Rola sit pokojowych ONZ w wojnie w Bośni i Hercegowinie (1992-1995) - wybrane zagadnienia, „Acta Universitatis Lodziensis. Folia Historica” 2018, t. 101, s. 191-207; G. CieCHAnOwski, Operacje pokojowe 
Przestawiony wcześniej wielonarodowy skład etniczny miasta musi wskazywać, iż rozpoczęte z początkiem wojny oblężenie Sarajewa nie było typowym przykładem prowadzonych walk i prostego, czarno-białego podziału na złych i dobrych, oblężonych i oblegających. Wielokrotnie media czy niektórzy politycy powielali przekaz „złych” Serbów - ostrzeliwujących mieszkańców całego miasta - czyli tylko Muzułmanów. Oczywiście, jak zauważa Krzysztof Krysieniel, „główną siłą atakującą była Armia Republiki Serbskiej, odpowiedzialna za barbarzyńskie czyny dokonywane na ludności cywilnej”"18 jednak część dzielnic i przedmieść Sarajewa (m.in. Grbavica) pozostała od początku wojny pod kontrolą Serbów. Natomiast w części miasta, obleganej przez VRS, mieszkały także poza Muzułmanami dziesiątki tysięcy Serbów i - w mniejszym stopniu - Chorwatów czy też wspominanych wcześniej osób określających się jako Jugosłowianie. Wielu z nich walczyło z własnej woli, czasem z przymusu, w szeregach Armii Republiki Bośni i Hercegowiny (Armija Republike Bosne i Hercegovine, ARBiH), jak np. gen. Jovan Divjak (Serb) ${ }^{19}$. Oblegający oskarżali takich ludzi, swoich współziomków, o zdradę.

Serbski dziennikarz, Željko Vuković, mieszkający w początkowym okresie oblężenia w Sarajewie, zauważył, że przywódcy Republiki Serbskiej od początku rozróżniali dwie kategorie sarajewskich Serbów - ,zakładników, na których mszczą się Muzułmanie”, i „największych serbskich bohaterów, którzy prędzej zginą, niżby mieli dopuścić, żeby serbskie Sarajewo wpadło w łapy Muzułmanów"20. Dodatkowo, jak stwierdziła Mirella Korzeniewska-Wiszniewska: „Przez Serbów z innych regionów serbscy mieszkańcy Sarajewa nazywani byli

ONZ wXX wieku, Toruń 2013, s. 261 i nast. Siedzibę główną UNPROFOR przeniesiono z Sarajewa do Zagrzebia.

${ }^{18}$ K. Krysieniel, op. cit., s. 176.

19 Divjak w wywiadzie z 1995 r. powiedział: „Jestem Serbem, ale jestem Bośniakiem. Urodziłem się w Belgradzie, ale od 30 lat mieszkam w Sarajewie, na Starym Mieście. Nigdy z moim sąsiadami Muzułmanami nie miałem najmniejszych zatargów. Dlatego walczę i będę walczyć z tym obłąkańczym pomysłem Karadžicia, że nie możemy żyć razem”. Generat jak ikebana, „Gazeta Wyborcza”, 5 IX 1995, AW (dostęp: 10 II 2021). Natomiast brytyjski dziennikarz Ed Vulliamy zauważył, że wielu Serbów, m.in. z Sarajewa, „,walczyło przeciwko pogromom dokonywanym w ich imieniu. Byli przeciwni podziałom według klucza wyznaniowego i lojalni wobec rządu, stojącego teoretycznie po stronie Muzułmanów - za co zostali później z oburzeniem odrzuceni przez polityczne przywództwo tychże Muzułmanów”. E. Vulliamy, Wojna umarta, niech żyje wojna. Bośniackie rozrachunki, Wołowiec 2016, s. 55-56.

20 Ž. Vuković, Sarajewo - miasto atrapa, Toruń 2002, s. 92. 
Serbami Aliji (w domyśle Izetbegovicia - ówczesnego prezydenta $\mathrm{BiH}$ ) lub też sarajewskimi Serbami (przy czym to ostatnie określenie, z pozoru neutralne, miało znaczenie pejoratywne)"21.

W obleganej stolicy Bośni i Hercegowiny dzielono często Serbów na „Serbów Karadžicia”, „serbskich agresorów”, „czetników” (oblegających i mieszkających np. w Grbavicy czy Pale) oraz na tzw. lojalnych. Ci „lojalni” także byli narażeni na niebezpieczeństwa każdego dnia, również stali pod ostrzałem w kolejkach po wodę czy żywność, ginęli od kul snajperów lub w wyniku ostrzału artyleryjskiego. Jednak wielu Muzułmanów czy Chorwatów nie dowierzało swoim serbskim sąsiadom, traktując ich często jako V kolumnę ${ }^{22}$. Niestety dochodziło także do ich prześladowań, uprowadzeń lub morderstw. Serbowie wielokrotnie byli ofiarami działań watażków i kryminalistów bośniackich, takich jak np. Juka, Caco, Celo. Ludzie ci w początkowym okresie wojny stali się bohaterami - obrońcami miasta, ale równocześnie prowadzili często przestępczą działalność, dręcząc ludność cywilną czy nawet UNPROFOR ${ }^{23}$. Te wszystkie czynniki miały wpływ na stopniowy proces zmniejszania się odsetka ludności niemuzułmańskiej, w tym serbskiej, w bośniackiej stolicy ${ }^{24}$.

$\mathrm{Na}$ obszarach Sarajewa, kontrolowanych przez stronę serbską, zwłaszcza w początkowym okresie wojny mieszkało także wielu nie-Serbów. Szybko się to jednak zmieniło $\mathrm{w}$ wyniku prowadzonych czystek etnicznych, zmuszania

${ }^{21}$ M. KorZeniewsKa-Wiszniewska, Serbowie jako mniejszość w warunkach transformacji politycznej w państwach bytej Jugostawii 1995-2016, Kraków 2017, s. 456.

22 Serbka mieszkająca w Sarajewie relacjonowała po wojnie: „Pamiętam, jak stałam w kolejce po wodę, gdy zaczął się kolejny ostrzał. Bałam się zawołać syna, który bawił się w parku obok, bo miał serbskie imię”. Cit.per: A. Uzelac, Na ziemiach odzyskanych, „Gazeta Wyborcza”, 19 IV 1996, AW (dostęp: 10 II 2021).

23 Więcej, vide: D. Warszawski [K. Gebert], Obrona poczty sarajewskiej, Warszawa 1995, s. 107 i nast.; A. KRzaK, Charakterystyka dziatań militarnych w Bośni w latach 1992-1993, [w:] Bośnia i Hercegowina 15 lat po Dayton. Przesztość - teraźniejszość - perspektywy. Studia i szkice, red. P. ChMielewski, S.L. SzCZesio, Łódź 2011, s. 41.

${ }^{24}$ Więcej o prześladowaniach Serbów w Sarajewie, vide: Ž. Vuković, Sarajewo..., s. 47 i nast.; K. Krysieniel, op. cit., s. 177; E. BUjwid-KURek, Rola Alii Izetbegovicia w ksztattowaniu muzutmańskiej wspólnoty narodowej Bośni i Hercegowiny, „Slavia Meridionalis” 2011, nr 11, s. 185. Warto także dodać, że sarajewscy Serbowie prowadzili działalność np. poprzez Serbską Radę Obywatelską (Srpsko građansko vijeće, SGV), której przewodził Mirko Pejanović. Więcej na ten temat piszą: M. Korzeniewska-Wiszniewska, Serbowie jako mniejszość..., s. 457; M. Pejanović, Through Bosnian Eyes. The Political Memoir of the Bosnian Serb, introd. by R.J. Donia, West Lafayette 2004, s. 187 i nast. 
ich do wyjazdu lub wymiany zakładników. Podobny proces zachodził również i w drugiej części miasta, dotykając Serbów i Chorwatów. W krótkim czasie zanikała więź pomiędzy sarajewianami, istniejąca przez lata. Jak zauważył Hervé Ghesquière: „Ludzie, którzy jeszcze wczoraj byli sąsiadami, stali się wrogami. Rozmawiali ze sobą, wygrażali sobie, czasem nawet sobie urągali. Walczący miesiącami gnili w błocie i zimowym śniegu, w letnim upale i kurzu"25.

Dawid Warszawski (Konstanty Gebert) w swej książce o konfliktach bałkańskich opisuje pewien charakterystyczny dla oblężenia miasta przykład. Tuż przez wybuchem wojny ktoś napisał na budynku poczty głównej w Sarajewie cyrylicą hasło: „To jest Serbia”. Pod spodem zaś, alfabetem lacińskim, ktoś inny dopisał: „To jest poczta, durniu”26.

Wielu sarajewian miało nadzieję, na początku wojny, że konflikt uda się szybko zakończyć, a politycy, przy wsparciu Zachodu, doprowadzą do pokojowego porozumienia. Vlatka Krsmanović, pracująca na Wydziale Nauk Politycznych Uniwersytetu Sarajewskiego, relacjonowała latem 1992 r.:

Większość mieszkańców Sarajewa czekała w swych domach z nadzieją, że przywódcy dogadają się i przyjdzie kres szaleństwa. Mieliśmy nawet pretensję do tych, którzy w kwietniu opuszczali miasto, choć wiedzieliśmy już, że na targu można kupić jedynie pokrzywę, mlecz i makaron. Sądziliśmy, że zapasy w zamrażarkach i spiżarniach wystarczą nam (...), racjonowaliśmy sobie papierosy i chleb, z którymi było coraz gorzej. I obcowaliśmy z sobą tak blisko jak nigdy przedtem - wielu dopiero w kwietniu i maju poznało swoich sąsiadów. (...) Wciąż mieliśmy nadzieję. A potem nadeszły obrazy zburzonych i spalonych budynków i osiedli, długich kolumn uciekających bądź wygnanych, dane o liczbie zabitych i zaginionych, na nowo uzbrojonych i zmobilizowanych ${ }^{27}$.

Natomiast nastolatka Zlata Filipović ${ }^{28} \mathrm{w}$ swoim dzienniku pod datą 9 kwietnia 1992 r. tak przedstawia pierwsze dni wojny:

${ }^{25}$ H. Ghesquière, Sarajewo. Rany sq nadal zbyt gtębokie, Kraków 2017, s. 36.

26 D. WArSZAwski [K. Gebert], Obrona poczty..., s. 5. Timothy Garton Ash, nawiązując do tej relacji Geberta, napisał: „Ja wszakże chciałbym dodać coś od siebie: «Tu jest Europa!». Wszystkie te rzeczy bowiem uczynili Europejczycy innym Europejczykom w Europie”. T. Garton Ash, Historia na goraco. Eseje i reportaże z Europy lat 90., Kraków 2000, s. 218.

27 V. Krsmanović, Jestem z Sarajewa, „Gazeta Wyborcza”, 16 VII 1992, AW (dostęp: 10 II 2021).

${ }^{28}$ Zapiski tej nastoletniej sarajewskiej uczennicy (ur. w 1980 r.), prowadzone od 1991 r. do 1993 r., przetłumaczone na wiele języków, są jednym z wielu świadectw życia codziennego w Sarajewie podczas wojny. Niektórzy porównywali jej pamiętnik z dziennikiem Anny Frank. Pod koniec 1993 r. Zlata 
Jakieś niebezpieczeństwo wisi nad tymi wzgórzami, które nas otaczają. Chociaż wydaje mi się, że trochę się uspakaja. (...) Czasem przez chwilę słychać strzelaninę, potem znowu jest cicho. Mama i tata chodzą do pracy. Kupują jedzenie w dużych ilościach. Chyba tak na czarną godzinę. (...) Jednak czuje się ogromne napięcie. Mama jest zrozpaczona, tata ją pociesza ${ }^{29}$.

Mieszkańcy miasta zdawali sobie sprawę z niebezpieczeństwa wiszącego nad stolicą "Jugosławii w miniaturze", lecz jeszcze nie wiedzieli, że najgorsze jest przed nimi...

Sarajewo, wciśnięte w wąską dolinę między stromymi zboczami i górami, było wymarzonym miejscem dla oblegających ${ }^{30}$. Ze swych stanowisk Serbowie widzieli jak na dłoni całe miasto. Żołnierze gen. Mladicia przygotowali się dobrze do oblężenia, od kwietnia 1992 r. setki sztuk ciężkiej broni (należącej pierwotnie do JNA): armat, moździerzy, wyrzutni rakietowych czy czołgów, rozmieszczonych na wzgórzach, było wykorzystywanych przez VRS do ataków na stolicę BiH w dzień i w nocy ${ }^{31}$. Bogdan Bogdanović stwierdził, że ostrzał Sarajewa miał na celu przekreślenie tego miasta jako pewnej idei, pisał o „rytualnym zabijaniu miasta” przez „nowoczesnych barbarzyńców”32.

W oblężeniu Sarajewa brały udział głównie jednostki Korpusu Sarajewsko-Romanijskiego VRS, którym dowodzili m.in. gen. Stanislav Galić i gen. Dragomir Milošević. Siły te liczyły kilkanaście tysięcy dobrze wyszkolonych i wyposażonych żołnierzy. Były one także wspierane przez serbskie jednostki paramilitarne oraz oddziały najemników ${ }^{33}$.

wyjechała wraz z rodzicami ze stolicy bośniackiej do Francji. „Jestem szczęśliwa, że opuszczam to piekło. Ludzie w tym kraju nagle się zmienili. Są jak zwierzęta" - powiedziała wówczas dziewczyna. Cit. per: D. WARSZAWski [K. GeBerT], Bezczynniepatrząc na zagtadę, „Gazeta Wyborcza”, 7 I 1994, AW (dostęp: 11 II 2021). Więcej o relacjach młodych dziewcząt z Sarajewa Zlaty Filipović, Nadii Halilbegović i Nirvany Zeljković, vide: M. ŚLAwsKa, Jak opowiedzieć śmierć? Oblężenie Sarajewa w relacjach dziewcząt, „Acta Universitatis Wratislaviensis. Slavica Wratislaviensia” 2019, t. 170, s. 41-51.

29 Z. Filipović, Dziennik Zlaty, przedm. T. Mazow iecki, Warszawa 1994, s. 31.

${ }^{30}$ P. Andreas, Blue Helmets and Black Markets. The Business of Survival in the Siege of Sarajevo, Ithaca-London 2008, s. 20.

${ }^{31}$ C.S. King, The Siege of Sarajevo, 1992-1995, [w:] Block by Block: The Challenges of Urban Operations, eds W.G. Robertson, L.A. Yates, Fort Leavenworth [2003], s. 249.

32 Vide: B. Bogdanović, Rytualne zabijanie miasta, „Krasnogruda” 1997, nr 6, s. 27-32; IDEM, Obrona miasta. List do sarajewskich przyjaciót, „Krasnogruda” 1997, nr 6, s. 99-101.

33 Vide: D. Wy branowski, Początki i pierwsze lata dziatalności Armii Republiki Bośni i Hercegowiny, [w:] Bośnia i Hercegowina 15 lat po Dayton..., s. 165-170; Prosecutor v. Radovan Karadžić..., s. 68-69; Balkan Battlegrounds..., s. 464-465; C.S. KING, op. cit., s. 250. 
Generał R. Mladić w przemówieniu w 1992 r. polecił swoim żołnierzom, by prowadzili ostrzał niekontrolowanych przez nich części Sarajewa: „Zasypujcie ich pociskami, aż oszaleją" ${ }^{4}$. Poziom intensywności ostrzału był różny w czasie oblężenia, według niektórych ekspertów średnio kilkaset pocisków dziennie, a w niektóre dni wzrastał do ponad 1000, 2000 lub nawet 3000. Warto dodać, że dochodziło również, chociaż w mniejszym stopniu, do ostrzału ze strony muzułmańskiej tych obszarów miasta, które były kontrolowane przez Serbów. Na jego skalę wpływała m.in. niewielka liczba ciężkiego sprzętu, którym dysponowali obrońcy z ARBiH. Czasami artyleria VRS odpowiadała na ostrzał wojsk bośniackich, chociaż - jak podkreślali eksperci podczas procesów przed Międzynarodowym Trybunałem Karnym dla byłej Jugosławii (International Criminal Tribunal for the former Yugoslavia, ICTY) - zwykle Serbowie w nieproporcjonalny sposób reagowali na działania drugiej strony, ostrzeliwując zarówno cele wojskowe, jak i cywilne. Czasami siły ARBiH celowo prowokowały stronę serbską, dokonując ataków m.in. z użyciem łatwych do przemieszczenia moździerzy, z budynków cywilnych, okolic szpitali, szkół czy z sąsiedztwa budynków ONZ, co potwierdzali np. przedstawiciele UNPROFOR ${ }^{35}$. Strategia ta miała przede wszystkim sprowokować bośniackich Serbów do nadmiernej reakcji, by chociażby w wyniku kolejnej masakry ludności cywilnej i presji mediów, doprowadzić do międzynarodowej reakcji, a może nawet interwencji państw Zachodu/ $\mathrm{NATO}^{36}$. Jednak to wojskom VRS, w tym jej dowódcom i przywódcom politycznym, udowodniono wiele przypadków użycia artylerii w czasie oblężenia Sarajewa, za co m.in. byli oskarżani i skazywani przez ICTY ${ }^{37}$.

${ }^{34}$ Cit.per: B. Demick, op. cit., s. 64.

35 Vide: Prosecutor v. Radovan Karadžić..., s. 1570 i nast.; Y. AkAshi, In the Valley Between War and Peace - Personalities I Met, Belgrade 2011, s. 110; Ž. Vuković, Zabijanie Sarajewa. Napisane w Sarajewie i w Belgradzie od maja do końca grudnia 1992 roku, Toruń 2000, s. 19.

${ }^{36} \mathrm{O}$ roli mediów podczas oblężenia miasta, vide: M. WALDENBERG, Rozbicie Jugostawii od separacji Stowenii do wojny kosowskiej, Warszawa 2003, s. 216-220; P. BRock, Media Cleansing: Dirty Reporting. Journalism and Tragedy in Yugoslavia, foreword by D. BINDER, Los Angeles 2006, passim.

37 Wśród osób odpowiedzialnych za oblężenie Sarajewa można wskazać m.in. wymienionych wcześniej gen. S. Galicia (skazanego w 2003 r. na 20 lat więzienia, po odwołaniu w 2006 r. wyrok zamieniono na dożywocie) i gen. D. Miloševicia (skazanego w 2007 r. na 33 lata więzienia, zaś po odwołaniu w 2009 r. Trybunał zmniejszył mu karę do 29 lat). Podczas procesu drugiego z generałów w 2007 r. sędzia Patrick Robinson stwierdził: „Nie było bezpiecznego miejsca w Sarajewie. Każdy mógł być zabity lub raniony w każdym miejscu i każdym momencie" 
Mieszkańcy bośniackiej stolicy mawiali, że każde ich wyjście z domu jest jak rosyjska ruletka. Niebezpieczny był ostrzał artyleryjski, ale także snajperski. Z każdym dniem przybywało zabitych i rannych. Sarajewianie szukali więc możliwości ukrycia się i ochronienia przed spadającymi pociskami, np. w prowizorycznych bunkrach czy też po prostu w piwnicach swych bloków lub domów. Predrag Pašić, były piłkarz, wspominał:

Kiedy budzisz się rano, myślisz tylko o jednym: żeby przeżyć. Nie masz w głowie innych myśli. (...) Dwa i pół roku wszyscy żyliśmy w piwnicy. W tamtym czasie młodsza córka nauczyła się chodzić. Swoje pierwsze kroki stawiała pod ziemią. To niesamowite, że udało nam się to przeżyć, znaleźć jedzenie, wodę $e^{38}$.

O strachu, ostrzale i ukrywaniu się pisze także wielokrotnie w swym dzienniku cytowana już Zlata Filipović:

Przerażające wybuchy. (...) Zeszliśmy do piwnicy - zimnej, ciasnej, okropnej piwnicy. (...) Jest okropna, ciemna i śmierdząca. Mama bardzo się boi myszy, miała więc podwójnego stracha. (...) Słyszeliśmy wybuchy pocisków i strzały. Słychać też było samoloty. W pewnym momencie zrozumiałam, że ta okropna piwnica jest naszym jedynym ratunkiem. Stała się nawet ciepła i miła. Tylko ona może nas ochronić w czasie tych okropnych walk. Słyszałam dźwięk rozbijanych szyb na naszej ulicy. Straszne. Zatykałam sobie uszy palcami, żeby nie dochodziły do mnie te przeraźliwe dźwięki. (...) Nie potrafię zapomnieć smrodu piwnicy, głodu, szyb, które fruwały w kawałkach, i strachu, kiedy wybuchały pociski. 12 godzin byliśmy bez jedzenia i picia, ale najgorszy był strach, kulenie się w kącie piwnicy i niewiadoma, co się może zdarzyćc ${ }^{39}$.

Dževad Karahasan, bośniacki pisarz, eseista i dramaturg, następująco opisywał pierwsze miesiące oblężenia:

Rok wojny w Sarajewie spędziłem w domu, w którym mieszkało: 11 Bośniaków (muzułmanów), siedmiu Serbów (prawosławnych), pięciu Chorwatów (katolików) i dwoje ludzi urodzonych w tzw. małżeństwach mieszanych (...). Przez rok razem zbiegaliśmy do piwnicy, dzieliliśmy się wodą i jedzeniem, częstowaliśmy się

- cit.per: A. Skieterska, 33 lata więzienia za dramat Sarajewa, „Gazeta Wyborcza”, 12 XII 2007, AW (dostęp: 10 II 2021). Później wśród skazanych znaleźli się także gen. R. Mladić i Radovan Karadžić.

38 Cit.per: A. Werner, M. KołodziejCZy k, Mecz to pretekst. Futbol, wojna, polityka, Kraków 2020, s. 63-64.

39 Z. Filipović, op. cit., s. 34, 36, 99. 
wzajemnie, ale też podkradaliśmy sobie to i owo. Kłóciliśmy się o miejsce w kolejce do zbierania deszczówki z rynien ${ }^{40}$.

Natomiast Ensar Arifović, który w czasie wojny był nastolatkiem (rocznik 1980), tak relacjonował życie w oblężonym mieście:

Gdy padały strzały, schodziłem do piwnicy, bo tylko tam było bezpiecznie. Każdy, kto miał dzieci, mieszkał z nimi w piwnicy. Ale mówi się tutaj, że podczas wojny relacje międzyludzkie w Sarajewie były najlepsze. Bo wszyscy musieli być razem. U nas w bloku znajdowało się 25 mieszkań, a wszyscy mieszkaliśmy razem pod ziemią. Może było tam z 200 metrów kwadratowych ${ }^{41}$.

Miejsca schronienia przed ostrzałem VRS w czasie dnia i/lub nocy organizowano także w budynkach użyteczności publicznej, jak np. w szkołach, sierocińcach, biurowcach itd. O takich schronach pisała dziennikarka Barbara Demick:

Szkoła imienia Razii Omanović mieściła się w murowanym budynku (...) w kuchni w podziemiu urządzono schron. (...) Był zdecydowanie nieprzyjemnym miejscem. Toalety znajdowały się na piętrze, a ludzie bali się wychodzić z piwnicy. Oddawali mocz do butelek, które trzymali pod łóżkami. (...) Złe warunki sanitarne powodowały częste kłótnie. (...) Schron przeciwbombowy, z którego korzystali mieszkańcy górnego odcinka ulicy Logavinej, mieścił się w dawnym sierocińcu. W schronie panowała klaustrofobiczna atmosfera. (...) W nocy materace rozkładano ciasno obok siebie i nie można było wstać, żeby na kogoś nie nadepnąć $c^{42}$.

Trwający wiele miesięcy stan ciągłego zagrożenia, ostrzał artyleryjski i snajperski, po pewnym czasie stały się dla niektórych czymś naturalnym, do czego można przywyknąć lub przyjąć, że jest to rodzaj loterii. Jak zauważył w 1994 r. szwedzki dziennikarz, Per Olov Enquist: „Po każdym ostrzale miasta zaczyna się loteria: kto tym razem zginął, a kto przeżył. Jutro, pojutrze, popojutrze odbędzie się kolejne losowanie. I trwa to już prawie dwa lata. Ludzie reagują rozmaicie

40 D. KARAHASAn, Tylko Karol May rozumiat nas - Indian, „Gazeta Wyborcza”, 29 VII 1995, AW (dostęp: 10 II 2021).

41 A. Werner, M. KołodziejCzy K, op. cit., s. 65. Arifović miał więcej szczęścia niż wielu jego kolegów, dzięki pomocy wujka, którym był Faruk Hadžibegić, były kapitan reprezentacji Jugosławii - wraz z mamą i rodzeństwem wyjechał z Sarajewa do Niemiec. Ojciec pozostał w oblężonym mieście jako żołnierz ARBiH. Później E. Arifović występował jako piłkarz w ligach kilku państw, w tym także w polskiej Ekstraklasie.

42 B. Demick, op. cit., s. 45-46. 
- niektórzy wybuchowo, jednak większość zamyka się w sobie. Na twarzach sarajewian nie widać ani łez, ani uśmiechów”ł3.

Dla mieszkańców stolicy BiH szczególnie niebezpieczne były moździerze, z których wielokrotnie ostrzeliwano miasto. Miejsca eksplozji pocisków moździerzowych na ulicach lub chodnikach nazywano „śladami smoczej łapy” (tragovi zmajeve šape). Niektóre z nich, po zakończeniu wojny, zalano czerwoną farbą, by pozostały jako pamiątki dramatycznych chwil i miejsca wielu tragedii oraz masakr z lat 1992-1995. Są nazywane „sarajewskimi różami”

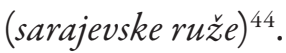

Celem artylerii VRS stawały się także liczne budynki, zarówno mieszkalne, jak i użyteczności publicznej. Jednym z takich obiektów była np. Biblioteka Uniwersytecka ze wspaniałymi i unikatowymi zbiorami ksiąg i pism. To niezwykłe dla ludzi nauki miejsce kilkakrotnie ostrzeliwano, a w nocy 25/26 sierpnia 1992 r. wybuchł pożar, w którym spłonęła znaczna część bogatych zbiorów ${ }^{45}$. Cel ataków stanowiły także liczne obiekty sportowe, m.in. wykorzystywane podczas Igrzysk Olimpijskich z $1984 \mathrm{r}$.

Kolejnym ważnym elementem krajobrazu życia codziennego w Sarajewie przez niemal cały czas oblężenia stali się snajperzy ${ }^{46}$. W wielu miejscach o niebezpieczeństwie ostrzegały sarajewian napisy i tabliczki „Pazi snajper” (Uwaga, snajper), „Opasna zona” (Strefa zagrożenia) czy „Run or R.I.P.” (Biegnij albo spoczywaj w pokoju). Mieszkańcy bośniackiej stolicy musieli więc często poruszać się biegiem po najbardziej niebezpiecznych częściach miasta, korzystać z osłony barykad czy też pojazdów UNPROFOR. Snajperzy byli niebezpieczni dla żołnierzy przeciwnej strony, ale także dla ludności cywilnej, w tym dzieci

43 P.O. EnQuist, Wielkie ktamstwo Europy, „Gazeta Wyborcza”, 4 II 1994, AW (dostęp: 11 II 2021).

${ }^{4}$ Vide: J. Górniak, Sarajewskie róże, „Polityka” 2012, nr 46, s. 108-113; M. SkrzeszewSKA, „Kap moje krvi poteče i Bosna ne presuši” - pamięć o oblężeniu Sarajewa, „Studenckie Zeszyty Naukowe Instytutu Filologii Słowiańskiej UJ” 2014, nr 2(6), s. 128-129. Do określenia „sarajewskich róż" nawiązuje także jedna z książek o pracy błękitnych hełmów: A.M. du Preez Bezdrob, Sarajevo Roses. War Memoir of a Peacekeeper, Cape Town 2004.

45 B. i P. Pomy каlscy, Jugostawia. Rozsypana uktadanka, Gliwice 2017, s. 29. Ocenia się, że utracono wówczas około $80 \%$ najważniejszych zbiorów dotyczących historii BiH. Jak zauważył K. Krysieniel, było to celowe działanie VRS, mające na celu zniszczenia symboli muzułmańskich w Sarajewie. K. Krysieniel, op. cit., s. 177-178.

46 Vide: J.L. Plaster, The History of Sniping and Sharpshooting, Boulder 2008, s. 610-614; Prosecutor v. Radovan Karadžić..., s. 1391 i nast. 
i starców. Ich ofiarami padali również żołnierze sił pokojowych, dziennikarze czy przedstawiciele międzynarodowych organizacji. Obcokrajowcy często mieli tę przewagę nad mieszkańcami Sarajewa, że chroniła ich kamizelka kuloodporna lub poruszali się opancerzonymi pojazdami. Sarajewianom pozostawał więc szybki bieg i nadzieja, iż będą mieli szczęście. Jak pisał Wojciech Tochman: „Nawet jeśli brakuje sił, trzeba biec. Każde przejście przez skrzyżowanie, może kosztować życie. Snajper strzela (...) i celuje w głowę. Trzeba biec do studni po wodę (ludzie ciągną wózki z kanistrami, albo pchają taczki); biec po chleb (raz na tydzień uda się zdobyć bochenek); biec do parku po opał"ł7.

Z kolei Z. Filipović tak opisywała drogę swojej matki do pracy:

Idzie [matka], jeśli nie strzelają, ale nigdy nie wiadomo, kiedy się to zacznie. Niebezpiecznie jest poruszać się po mieście. Szczególnie niebezpieczne jest przejście przez nasz most, bo strzelają snajperzy. Trzeba biec. Za każdym razem, kiedy mama wychodzi, patrzymy z tatą przez okno, jak biegnie. Mama mówi: „Nigdy nie myślałam, że Miljacka jest taka szeroka. Biegniesz, biegniesz, biegniesz i masz wrażenie, że nigdy się nie znajdziesz na drugim końcu mostu”48.

O sposobie poruszania się w Sarajewie pisał także polski korespondent, Stanisław Tekieli:

Obowiązuje specjalny, wojenny krok, rozpisany na trzy rytmy. Pierwszy, spacerowy, uskuteczniać można tam, skąd nie widać wzgórz na lewym brzegu rzeki. Drugi, przyspieszony, na terenach otwartych, ale oddalonych od wzgórz o co najmniej 700 metrów (podobno z większej odległości bardzo trudno trafić w szybko idącego człowieka). Trzeci to kłus, jakim sarajewianie pokonują otwarte miejsca leżące 200 czy 300 metrów od serbskich linii, np. niektóre skrzyżowania na głównej ulicy (te najgroźniejsze obstawione są kontenerami, ciężarówkami, autobusami lub metalowymi czy betonowymi płytami, skrywającymi przechodniów przed okiem snajpera). (...) Obserwowałem to przebieganie trefnych skrzyżowań dziesiątki razy i wydawało mi się, że absolutnie wszyscy, dzieci, kobiety i starcy, biegną w dokładnie tym samym tempie, tak samo, „z jednej nogi” startują na ostatnim osłoniętym metrze i tak samo finiszują, płynnie przechodząc do marszu. Tak jakby całe miasto przeszło przez te wojenne miesiące ponowną naukę chodzenia ${ }^{49}$.

47 W. Tochman, Ściemnia się, „Gazeta Wyborcza”, 9 I 1993, AW (dostęp: 11 II 2021).

48 Z. Filipović, op. cit., s. 52.

49 S. Tekieli, Snajper w tle, „Gazeta Wyborcza”, 24 III 1993, AW (dostęp: 10 II 2021). 
Chwila zatrzymania na otwartej przestrzeni groziła postrzałem lub śmiercią. Sarajewianie mawiali, że snajperzy są tak blisko, że mogą nawet wybrać, które oko ma być celem ${ }^{50}$.

Jednym z najbardziej charakterystycznych i groźnych miejsc w Sarajewie podczas oblężenia dla jej mieszkańców, jak i obcokrajowców, była tzw. Aleja Snajperów. Tak nazywano nieoficjalnie m.in. jedną z głównych alei sarajewskich: ulicę Smoka z Bośni (Zmaja od Bosne), którą trzeba było pokonać, by dostać się np. z lotniska do centrum miasta. W czasie oblężenia zyskała ponurą sławę, stając się miejscem śmierci lub zranienia wielu osób oraz ostrzału pojazdów, samochodów, tramwajów ${ }^{51}$. W jej pobliżu znajdował się m.in. hotel Holiday Inn - podczas wojny miejsce zakwaterowania wielu reporterów zagranicznych. Francuski dziennikarz, Hervé Ghesquière, tak wspomina tę niebezpieczną trasę:

Serbscy strzelcy wyborowi, rozlokowani na pobliskich wzgórzach, uwielbiali mierzyć do samochodów i nielicznych przechodniów, którzy zapuścili się na tę drogę śmierci. W tamtym okresie pokonywałem ją co najmniej dwa razy dziennie, aby dostać się do centrum Sarajewa. (...) Pędziłem moim małym Peugeotem 205, puszczając zespół Queen na cały regulator. (...) Wciskałem gaz do dechy, żeby nie dosięgnęły mnie kule i pociski. To była rosyjska ruletka. (...) Przez przednią szybę widziałem cienie ludzi uciekających przed strzałami. Każdy wystrzał wywoływał dreszcz, wiedziałem, że moje życie wisi na włosku. Koncentracja była najlepszą obroną przed strachem i jedynym sposobem, żeby nie zdechnąć pośrodku piekta ${ }^{52}$.

Oczywiście większość działań snajperów w Sarajewie była podejmowana przez siły serbskie, jednak nie można zapominać również o drugiej stronie - ARBiH. Także jej wojska używały snajperów przez cały czas trwania konfliktu, w tym przeciwko serbskiej ludności cywilnej, np. z Grbavicy ${ }^{53}$.

${ }^{50}$ B. Demick, op. cit., s. 64.

${ }^{51}$ Do tej nazwy nawiązuje m.in. polskie tłumaczenie tytułu anglojęzycznego filmu z $1997 \mathrm{r}$. w reżyserii Michaela Winterbottoma (angielski tytuł: Welcome to Sarajevo), na motywach książki Michaela Nicholsona Natasha's Story.

52 H. GHeSQuière, op. cit., s. 29-30.

53 Więcej, vide: Prosecutor v. Radovan Karadžić..., s. 1398-1399. Željko Vuković opisuje w jednej ze swych książek snajpera walczącego przez dwa i pół miesiąca po stronie muzułmańskiej. Zdecydował się na ten krok po tym, jak zobaczył umierającą na ulicy dziewczynkę, trafioną odłamkiem. „Byłem przekonany, że dokonuję czynów bohaterskich. Nie zawracałem sobie głowy rozmyślaniem. (...) Wszyscy po tamtej stronie byli dla mnie wrogami, których należy zabijać. Tak jak oni nas zabijają. Bez wyboru. Czułem się mścicielem. Wy nas, a my was. Oko za oko, ząb za ząb. (...) Miałem 
Poza wycelowanymi karabinami snajperów i ostrzałem artyleryjskim z obu stron kolejnym wyzwaniem dla tysięcy mieszkańców Sarajewa była kwestia żywności. Gdy na początku wojny miasto zostało odcięte przez oblegające oddziały serbskie, szybko okazało się, że zaczyna brakować zaopatrzenia. Ponieważ urwał się kontakt $\mathrm{z}$ otoczeniem zewnętrznym, z terenami wiejskimi, w krótkim czasie ze sklepów i targów zniknęły też wszystkie produkty spożywcze. Sklepy zamieniały się w znane nam z czasów tzw. realnego socjalizmu i kartek żywnościowych lokale z pustymi półkami. Zanim lotnisko sarajewskie zostało przejęte przez UNPROFOR, w bośniackiej stolicy realne stawało się widmo głodu, gdyby dalej do miasta nie docierały dostawy z zewnątrz. Dlatego ważnym celem dla przedstawicieli Narodów Zjednoczonych było otwarcie mostu powietrznego, dzięki któremu do Sarajewa mogły przylatywać samoloty z tysiącami ton pomocy humanitarnej, w tym żywności, dla ludności cywilnej.

Nim to nastąpiło, w wielu domach i rodzinach pojawił się problem z zapasami żywności, co wiązało się z kolejną uwidaczniającą się coraz częściej komplikacją życia codziennego - niedoborem prądu. Sarajewianie próbowali gromadzić zapasy jedzenia, jednak w ciągu pierwszych tygodni wojny 1992 r., gdy brakowało energii elektrycznej, nadeszła fala upałów i zgromadzone w lodówkach czy zamrażalnikach jedzenie mogło się zepsuć. Tak opisuje to w swym dzienniku Z. Filipović pod datą 5 czerwca 1992 r.:

Nie ma prądu. Od wielu godzin boimy się o jedzenie, które jest w zamrażarce. To już nasze ostatnie zapasy. Szkoda by było, gdyby miały przepaść. Mamy trochę mięsa, warzyw i owoców. (...) Tata znalazł na strychu stary piec na drewno. (...) Rozpaliliśmy piec na podwórku i ratujemy jedzenie z lodówki. Ugotowaliśmy wszystko, a Bobarowie przyszli pomóc nam to zjeść. Ale uczta. Była cielęcina, kurczak, kalmary, strucla z wiśni, pita z ziemniaków i mięsa. Różności. Szkoda tylko, że musieliśmy to wszystko zjeść na raz. Chyba się przejedliśmy. (...) Znalezienie żywności staje się w Sarajewie dużym problemem. Nic nie można kupić, a dorośli mają kłopoty z kawą i papierosami. Zużywa się ostatnie zapasy. Boże, czy przyjdzie nam jeszcze głodować? ${ }^{54}$

Dla większości rodzin taka uczta była ostatnią podczas rozpoczynającego się długiego oblężenia. Później wielu mieszkańców miasta, pomimo wsparcia

za zadanie wywoływać panikę, nie dopuścić do tego, by ludzie mogli swobodnie poruszać się". Cit. per: Ž. Vuković, Zabijanie..., s. 33-34.

${ }_{54}$ Z. Filipović, op. cit., s. 46. 
różnych organizacji międzynarodowych, miało problemy ze zdobyciem podstawowych artykułów żywnościowych. Skutkiem długotrwałego niedożywienia było pojawiające się uczucie głodu 55 , a u części sarajewian - znaczna utrata wagi ${ }^{56}$. Pod koniec grudnia 1992 r. Z. Filipović zapisała:

Patrzę na tatę. Naprawdę schudł. Na wadze jest to $25 \mathrm{~kg}$, a jak tak na niego patrzę, wydaje mi się, jeszcze więcej. Nawet okulary są jakby na niego za duże. Mama też schudła. Jakoś się skurczyła, wojna narysowała jej zmarszczki... Boże, co ta wojna robi z moich rodziców. Przecież oni nie przypominają już mojej mamy i mojego taty $\mathrm{y}^{57}$.

Trwające walki uniemożliwiały otwarcie mostu powietrznego przez kilka tygodni, na szczęście przełomem okazała się wizyta prezydenta Francji. François Mitterand przybył 28 czerwca 1992 r. na lotnisko Butmir ${ }^{58}$, co umożliwiło rozpoczęcie dostaw pomocy humanitarnej, głównie drogą lotniczą, do Sarajewa. Ta gigantyczna operacja logistyczna, w której wzięli udział przedstawiciele wielu organizacji międzynarodowych i państw, odegrała kluczową rolę w przetrwaniu

55 Jak pisał Ž. Vuković: „Uczucie głodu jest szczególne. Nigdy dotąd nie byłem obżartuchem, a zwłaszcza nie w czasie wojny. Jednak uczucie głodu doprowadzało mnie do szaleństwa. Pochłaniam ogromną porcję ryżu lub makaronu. A za pół godziny czuję głód”. Autor martwił się także o najmłodszych, gdyż dzieci ciężko znoszą głód. Dla nich szybko nieznanymi pojęciami stawały się np. czekolada, ciastka, słodycze, ale także jabłka, gruszki, pomarańcze, banany czy winogrona itd. Ž. Vuković, Zabijanie..., s. 42-43.

${ }^{56}$ Jak pisze K. Krysieniel, każdy mieszkaniec stolicy schudł podczas wojny średnio o $12 \mathrm{~kg}$. K. KRYSIENIEL, op. cit., s. 178.

57 Z. Filipović, op. cit., s. 82. Także B. Demick podaje przykłady mieszkańców - poznanych podczas swych pobytów w Sarajewie - którzy znacznie tracili na wadze w wyniku tzw. sarajewskiej diety, chudli nawet o $60 \mathrm{~kg}$ ! Natomiast pewne małżeństwo, otrzymujące niemal wyłącznie racje żywnościowe z ONZ, od początku wojny straciło po $20 \mathrm{~kg}$. Czasami trafiały do nich paczki wysyłane przez krewną z Paryża, jednak większość z nich ginęła lub była rozkradana. Te, które docierały do potrzebujących, jak stwierdziła mieszkanka Sarajewa, zawierały „czekoladki i rozmaite upominki. [Krewna] nie zdawała sobie sprawy, że brakuje nam podstawowych produktów, takich jak mąka, cukier czy margaryna”. B. DEмICK, op. cit., s. 70-72.

58 Vide: M. MiкоŁAJCZy к, François Mitterrand wobec rozpadu Jugostawii w latach 1991-1995, „Balcanica Posnaniensia. Acta et studia” 2013, [t. 20], s. 206-209; Ch. Jones, François Mitterrand's Visit to Sarajevo, 28 June 1992, „Diplomacy and Statecraft” 2017, vol. 28, no. 2, s. 296-319. Bośniacki przywódca Alija Izetbegović zaapelował do francuskiego prezydenta kilka dni wcześniej o pomoc: "Jesteśmy nowym warszawskim gettem. Wszyscy musimy umrzeć" - cit.per: Sarajewo odblokowane, „Gazeta Wyborcza”, 29 VI 1992, s. 1. 
oblężonego miasta ${ }^{59}$. Akcję koordynował Urząd Wysokiego Komisarza Narodów Zjednoczonych ds. Uchodźców (United Nations High Commisioner for Refugees, UNHCR). Trzeba jednak także pamiętać, że wielokrotnie most powietrzny był zawieszany ze względów bezpieczeństwa (czasami na kilka tygodni lub nawet miesięcy) i dochodziło do wielu incydentów. Odbijało się to na dostawach i pomocy, która trafiała codziennie do tysięcy sarajewian, szczególnie gdy nie docierały konwoje drogą lądową, często blokowane przez strony konfliktu (głównie przez Serbów) ${ }^{60}$. Dodatkowo, gdy już pomoc znajdowała się w mieście, pojawiało się pytanie, czy zawsze trafia ona do najbardziej potrzebujących. Jak zauważył polski dziennikarz, Jan Piekło: „Żywność przywożą do miasta konwoje z pomocą humanitarną. Pracownicy misji Wspólnoty Europejskiej nie są wcale pewni, czy trafia ona do najbardziej potrzebujących. Trudno jest w tych warunkach kontrolować rozdział żywności czy leków. Część z pewnością znajdzie się na czarnym rynku, jak duża - nie wiadomo"61. Konwoje przybywały lądem z chorwackiego Splitu do Sarajewa, tzw. drogą życia. Warto dodać, że wielokrotnie dochodziło do ataków na te transporty, w których były ofiary śmiertelne i ranni wśród kierowców oraz chroniących je żołnierzy w błękitnych hełmach.

Ponadto zdarzały się incydenty, gdy wygłodzeni ludzie starali się zdobyć żywność i wdzierali się siłą do magazynów z pomocą humanitarną. Do takiej sytuacji doszło m.in. na początku lipca 1992 r. w czasie wizyty Wysokiego Komisarza ONZ ds. Uchodźców, Sadako Ogaty. Japonka rozmawiała z kilkudziesięcioma osobami oczekującymi dostaw żywności przed jednym z magazynów Narodów Zjednoczonych w stolicy BiH. Chociaż tłum sarajewian wiwatował początkowo na jej widok, gdy odeszła, zniecierpliwieni ludzie siłą wtargnęli do magazynu. Niestety - dla nich - okazał się pusty ${ }^{62}$.

59 Od lata 1992 r. do stycznia 1996 r. podczas blisko 13000 lotów dostarczono ponad 160000 ton pomocy humanitarnej, w tym aż blisko 145000 ton żywności. W niektórych miesiącach przy użyciu mostu powietrznego do Sarajewa trafiało ponad $85 \%$ potrzebnych towarów i produktów. Vide: Uchodźcy świata 2000. 50 lat pomocy humanitarnej, Warszawa 2000, s. 251; P. ANDREAS, op. cit., s. 39.

${ }^{60}$ Przedstawiciele stron konfliktu, jak chociażby bośniaccy Serbowie czy Chorwaci, często domagali się „opłat” lub pozostawienia części pomocy humanitarnej, np. 30\%, w zamian za zgodę na przejazd przez punkty kontrolne.

${ }^{61}$ J. PiekŁo, Sarajewo: agonia nadziei, [w:] Wezet batkański, red. J. PiekŁo, S. Wilkanowicz, Kraków 1999, s. 51.

${ }^{62}$ W Sarajewie gtód, „Gazeta Wyborcza”, 9 VII 1992, AW (dostęp: 20 II 2021). 
Mieszkańcy Sarajewa otrzymywali różne produkty pierwszej potrzeby, głównie za pośrednictwem UNHCR. Wśród podstawowych artykułów spożywczych można wymienić np.: mąkę, olej, cukier, ryż, konserwy, makarony, produkty mleczne (jak chociażby mleko w proszku czy ser feta), suszoną fasolę. Czasami do sarajewian trafiały nietypowe produkty, jak chociażby amerykańskie wysokoproteinowe suchary, pamiętające jeszcze wojnę w Wietnamie (z lat sześćdziesiątych!), drogą wodę mineralną - przysyłaną przez Francuzów - czy całe sterty szarego mydła. Niektórzy mieszkańcy Sarajewa twierdzili, że pomoc humanitarna, którą otrzymywali, to często stare nadwyżki, których pozbywali się przedstawiciele państw zachodnich. Ludzie opowiadali także, iż wiele artykułów wysokiej jakości (jak np. kompoty owocowe i czekolady), chociaż były wysłane, rzadko docierały do potrzebujących - albo konfiskowano je po drodze, albo - w najlepszym wypadku - trafiały na czarny rynek ${ }^{63}$. Ponownie przykład z dziennika Z. Filipović z lipca 1992 r.:

Dostaliśmy paczkę z ONZ. Pomoc humanitarna. W paczce było sześć konserw z wołowiną, pięć rybnych, dwa sery, trzy kg proszku do prania, pięć mydeł, dwa kg cukru i pięć litrów oleju. Paczka jest super. Tylko tata musiał stać cztery godziny w kolejce, żeby ją dostać ${ }^{64}$.

Poza wsparciem społeczności międzynarodowej mieszkańcy Sarajewa mogli uzupełniać swoje zapasy, robiąc zakupy na bazarach czy korzystając z czarnego rynku, ewentualnie starać się wytworzyć żywność we własnym zakresie. Jednak towary, które sprzedawano na targach w stolicy $\mathrm{BiH}$, były horrendalnie drogie. Do ich nabycia często niezbędne stawało się posiadanie amerykańskich dolarów, niemieckich marek lub innych poszukiwanych artykułów na wymianę. Jak pisała B. Demick:

63 Vide: I. Mače K, Sarajevo Under Siege. Anthropology in Wartime, Philadelphia 2009, s. 6768; B. Demick, op. cit., s. 67, 74; W. Tochman, Kiedy otworzq miasto, „Gazeta Wyborcza”, 4 III 1994, AW (dostęp: 20 II 2021).

64 Z. Filipović, op. cit., s. 54. Natomiast W. Tochman opisał w jednym z reportaży z początku 1993 r. pewną sarajewską rodzinę, która otrzymywała miesięczny przydział na trzy osoby: 1 kg ryżu, cukru, 1 loleju i jedną konserwę - „ciągle to zbyt mało, ale przynajmniej cokolwiek. Żywność zawsze jest sucha”. Jedna z tych osób zdradzała dziennikarzowi: „Jajko widziałam dziewięć miesięcy temu. Dopóki nie było śniegu, wychodziłam przed blok, rwałam trawę i siekałam na chleb. To były nasze witaminy. Chciałabym zjeść jabłko i pomidora”. W. Tochman, Ściemnia się... 
Czarny rynek był żywym symbolem zapaści ekonomicznej. Targ funkcjonował na zasadzie prymitywnego barteru. Mieszkańcy miasta przychodzili tu, by wymienić adidasy, z których wyrosły ich dzieci, na cukier bądź jakiś element instalacji wodno-kanalizacyjnej czy elektrycznej, albo przehandlować maleńkie puszeczki z rybą z darów organizacji humanitarnych na coś potrzebniejszego. Najbardziej poszukiwanymi towarami były kawa i papierosy (...). Ceny zmieniały się gwałtownie w zależności od tego, jak szczelna była w danym momencie blokada Sarajewa. (...) Prawie wszystkie produkty spożywcze sprzedawane na czarnym rynku pochodziły z pomocy humanitarnej ONZ. (...) Inne towary przemycono z baz sił pokojowych. (...) Powszechnie znienawidzony targ stał się filarem ekonomii oblężonego miasta ${ }^{65}$.

Kolejnym ważnym dla sarajewian i handlu w oblężonym mieście czynnikiem stało się uruchomienie w 1993 r. tunelu, z którego korzystali wojskowi i cywile. Dzięki temu podziemnemu przejściu do Sarajewa docierały np. dostawy broni, amunicji, paliwa, leków, żywności, ale także towarów luksusowych, które później sprzedawano z zyskiem. Tunel służył także do przemieszczania ludzi ze stolicy $\mathrm{BiH}$ i do niej ${ }^{66}$. Wiele osób, po dwóch stronach barykady, dorabiało się ogromnych fortun dzięki czarnorynkowym interesom.

Mieszkańcy stolicy BiH wyprzedawali wartościowe przedmioty czy sprzęty, czasami mało przydatne w nowej rzeczywistości (np. elektronika, komputery, samochody itd.). Dzięki temu mogli kupić potrzebne do życia produkty. Jednak przeciętnego człowieka nie było stać na takie zakupy. W maju 1993 r. Z. Filipović stwierdzała ze smutkiem:

Obejrzałam sobie bazar. Niczego w Sarajewie nie brakuje. Ludzie sprzedają wszystko. (...) Wstrętne jest to, że ktoś kradł, ale jeszcze gorsze, że sprzedaje to teraz za dewizy... Trzeba było widzieć te wszystkie rzeczy do jedzenia. A my jesteśmy głodni. (...). Dla kogo to wszystko, skoro my, zwykli ludzie, nie możemy sobie nic kupić $^{67}$.

Najbardziej znanym targowiskiem, zwłaszcza za sprawą jego ostrzałów i trzech masakr ${ }^{68}$, było Markale. Miejsce to, jak zauważył K. Gebert,

${ }^{65}$ B. DeMICK, op. cit., s. 137-138.

${ }^{66}$ Więcej na ten temat, vide: R.J. Donia, op. cit., s. 356-357; M. Skrzeszewska, op. cit., s. 129-130. Wladze BiH przystąpiły do budowy drugiego tunelu, jednak został on ukończony dopiero pod koniec wojny.

67 Z. Filipović, op. cit., s. 101-102.

${ }^{68}$ W maju 1992 r., w lutym 1994 r. oraz w sierpniu 1995 r. Te wydarzenia miały decydujący wpływ na postawę społeczności międzynarodowej wobec konfliktu bośniackiego. 
przypominało „warszawski Bazar Różyckiego sprzed lat. Handluje się tam rzeczami osobistymi, żywnością z pomocy humanitarnej, benzyną, produktami z przydomowych ogródków. Stragany sklecone z desek i rur stoją na gołej ziemi"69.

Niektóre rodziny otrzymywały wsparcie dzięki swym bliskim, znajomym - osobom pracującym np. jako tłumacze, kierowcy czy przewodnicy dla organizacji międzynarodowych, sił pokojowych ONZ czy zagranicznych dziennikarzy. Za swoją pracę dostawali wynagrodzenie m.in. w obcej walucie lub w pilnie poszukiwanych towarach, zwłaszcza żywności. Wspomina o tym w swoim dzienniku inna nastolatka z Sarajewa, Nadia Halilbegović ${ }^{70}$. Jej brat, Sanel, rozpoczął pracę dla przedstawicieli Narodów Zjednoczonych jako tłumacz. Gdy zapytano go, czy chce, by płacono mu pieniędzmi lub jedzeniem, wybrał tę drugą opcję. Dzięki temu mógł uszczęśliwić swoich bliskich, w tym siostrę. Jak napisała pod datą 5 lipca 1993 r.: „Od miesięcy nie widziałem ani jednego owocu. (...) Pewnego popołudnia [Sanel] przyniósł mi pomarańczę. Przez wiele godzin trzymałam ją w dłoni, śmiejąc się i płacząc. Czułam, jakbym trzymała w mojej dłoni cały świat"

Była jeszcze jedna opcja, by skorzystać ze wsparcia w zakresie żywienia. Jak zauważał Ž. Vuković, kto był „udokumentowanym wyznawcą”, miał możliwość otrzymania dodatkowych racji żywnościowych, np. mąki, ryżu, makaronu, soli, cukru. „Głód pchnął mieszkańców Sarajewa do meczetów i kościołów” - twierdził serbski dziennikarz. Takiej pomocy udzielały np. religijne organizacje charytatywne, jak chociażby „Merhamet” (muzułmańska), „Caritas” (katolicka), czy w mniejszym stopniu „Dobrotvor” (prawosławna) ${ }^{72}$.

Podczas oblężenie Sarajewa wyżywienie wieloosobowej rodziny było więc wyzwaniem i wymagało dużej pomysłowości i kreatywności. Powstawały

69 D. Warszawski [K. Gebert], Zabić Sarajewo, „Gazeta Wyborcza”, 7 II 1994, s. 1.

${ }^{70}$ Urodzona w 1979 r. Nadia Halilbegović, podobnie jak Z. Filipović, pisała dziennik w trakcie oblężenia Sarajewa. Została ranna w 1992 r., a fragmenty jej relacji były publikowane oraz odczytywane podczas audycji radiowych. Pod koniec wojny nastolatka opuściła stolicę $\mathrm{BiH}$ i wyjechała do Stanów Zjednoczonych, a następnie do Kanady. Prowadzi działalność na rzecz pokoju i dzieci, które ucierpiały w trakcie konfliktów zbrojnych. Jej dziennik był tłumaczony na różne języki i także porównywany do dzieła A. Frank. Więcej o tej postaci: http://www.nadjapeace.com (dostęp: 22 II 2021); M. ŚLAWSKA, Jak opowiedzieć śmierć..., s. 43.

${ }^{71}$ N. Halilbegovich, My Childhood Under Fire. A Sarajevo Diary, Toronto 2006, s. 45 (tu i dalej przekład mój-S.L.S).

${ }^{72}$ Ž. Vuković, Zabijanie..., s. 42 . O takiej pomocy, vide: N. Halilbegovich, op. cit., s. 31. 
przeróżne „przepisy wojenne”, kulinarne wynalazki w rodzaju „pasztecików z powietrzem”, „kotletów schabowych” z czerstwego chleba, „frytek” z mąki i drożdży czy przepisy na erzac kawy lub erzac z suszonej soczewicy ${ }^{73}$.

Wielu sarajewian starało się wytworzyć samodzielnie żywność, powstawały przydomowe miniogródki - często na balkonach, kurniki, używano doniczek, by korzystając m.in. z nasion dostarczanych przez społeczność międzynarodową (np. Międzynarodowy Komitet Pomocy Freda Cuny’ego ${ }^{74}$ ), hodować warzywa czy przyprawy. Według dziennika Z. Filipović:

Zwykli ludzie, tacy jak my, dostają paczki, a teraz jeszcze, żeby PRZEŻYĆ, hodują warzywa, gdzie tylko się da. W oknach i na balkonach są ogródki. Zamiast kwiatów rośnie sałata, cebula, pietruszka, marchew, buraki, pomidory i nie wiem, co tam jeszcze. My też zamiast naszych pięknych pelargonii mamy sałatę, cebulę, pietruszkę i marchew. Resztę nasion oddaliśmy cioci Melicy, bo ona ma ogródek ${ }^{75}$.

Kolejnymi utrudnieniami w życiu codziennym mieszkańców Sarajewa były stałe problemy z dostawami prądu, gazu czy wody. Przez wiele miesięcy te niezbędne w normalnym życiu media pojawiały się w domach sarajewian sporadycznie, niekiedy co kilka dni, dosłownie na kilka godzin. Pewnym symbolem stało się hasło Nema ništa (Niczego nie ma). Wykorzystywano więc np. masowo akumulatory, konstrukcje i wynalazki czasów oblężenia, jak najróżniejsze piece, lampy, świece i kaganki, wózki ze stołu czy z sanek, rowery podłączane do radia lub telewizora (kręcenie pedałami wytwarzało prąd) itd. Wymyślano nowe sposoby gotowania, np. rozpalając małe ogniska na balkonach. Podłączano się niekiedy nielegalnie pod urzędy, instytucje państwowe lub ważnych sąsiadów. Gdy chwilowo włączano media, Sarajewo na krótko budziło się do życia ${ }^{76}$. Krótka relacja z trzech dni w dzienniku Z. Filipović:

Od 9.45 mamy wodę. Cały czas nie ma prądu. 10.30 - woda jeszcze jest. 12.00 - nie ma wody, ale jest prąd. (...) Mama przynosi wodę. (...) Zapomniałam już jak to jest, gdy woda leci z kranu i można się wykąpać. My robimy to za pomocą dzbana. Dzban zastępuje nam prysznic. Pranie bielizny i mycie naczyń jak w średniowieczu. (...)

73 Vide: B. DeMick, op. cit., s. 67-73.

${ }^{74}$ L. Weschler, Praktyczny cztowiek od katastrof, „Gazeta Wyborcza”, 14 I 1994, AW (dostęp: 11 II 2021).

75 Z. Filipović, op. cit., s. 102.

${ }^{76}$ Vide: B. Deмick, op. cit., s. 76 i nast.; S. STOvRAG, Krótka historia wojennych wynalazków, „Gazeta Wyborcza”, 4 XII 1995, AW (dostęp: 10 II 2021). 
Nie ma prądu i zanosi się, że prawdopodobnie długo go nie będzie. Baterie są wyczerpane. Tata przyniósł akumulator z samochodu i podłączył go do radia. Tak więc teraz możemy słuchać wiadomości. Muzyki nie słuchamy, bo trzeba oszczędzać akumulator ${ }^{77}$.

Kolejne przykłady z dziennika N. Halilbegović z grudnia 1992 r. i października 1993 r.:

Bez wody, bez prądu, bez gazu. Niczego nie ma! (...) O 7 rano włączono prąd. Wszyscy się spieszyli. Kąpiel, pranie, prasowanie, gotowanie, odkurzanie i sprzątanie przed ponownym wyłączeniem prądu. Kilka godzin elektryczności daje nam trochę normalności ${ }^{78}$.

Wyzwaniem stawało się przetrwanie bez ogrzewania, gazu, prądu i opału zimą, gdy w Sarajewie temperatura spadało zdecydowanie poniżej zera. Śnieg potrafił spaść już we wrześniu czy październiku i utrzymywać się przez kilka miesięcy. Aby ogrzewać swe domy i mieszkania, sarajewianie wycinali drzewa, spalali szafy, regały, ubrania, książki, elementy samochodów ${ }^{79}$. Pierwszą zimę oblężonego miasta tak opisywał w styczniu 1993 r. J. Piekło:

Słychać stuk siekier. Grupa mężczyzn pracowicie rąbie drzewa. Coraz ich mniej w Sarajewie. (...) Ludzie palą w piecu drewnianymi żaluzjami i książkami. Przedmiotem pierwszej potrzeby jest tu żelazny piecyk znany w Polsce pod popularną nazwą „kozy”, którym ludzie ogrzewają wnętrza i na którym gotują ryż i podgrzewają zdobyte konserwy. (...) W domach widać więc rzędy dymiących z okien rur. Tam, gdzie dymu nie widać, nie da się żyć - temperatura na zewnątrz spadła do $-20^{\circ} \mathrm{C}$. Starsi ludzie, którzy nie potrafią uzbierać zapasu opału, zamarzają w swoich mieszkaniach ${ }^{80}$.

77 Z. Filipović, op. cit., s. 50, 60, 66.

${ }^{78}$ N. Halilbegovich, op. cit., s. 33, 49.

79 O wykorzystywaniu książek do ogrzewania mieszkania podczas zimy pisze K. Gebert, przytaczając przykład Zdravka Greby: „Zdravko ma szczęście. Jako profesor prawa na sarajewskim uniwersytecie ma duży księgozbiór. Codziennie z kilku tomów wyrywa kartki, starannie, przy samym grzbiecie, żeby nie marnować papieru. Kartki moczy się w wodzie, a następnie z papierowej masy formuje się brykiety, które schną potem na balkonie. (...) Ale i tak trudno będzie ogrzać «ciepłą izbę», czyli pokój, w którym stoi piecyk typu koza, bo w sąsiednim pokoju pocisk wyrwał pół ściany”. D. Warszawski [K. GeberT], Obrona poczty..., s. 94.

${ }^{80}$ J. PiekŁo, op. cit., s. 48. O wycinaniu drzew wspomina także N. Halilbegović dodając - w listopadzie 1992 r. - że przez tę wycinkę nie widzi zachodzących zmian w przyrodzie i pięknych jesiennych kolorów. N. Halilbegovich, op. cit., s. 30. 
Oblężenie było niezwykle trudnym czasem dla osób starszych, schorowanych, pozbawionych opieki rodziny, znajomych czy sąsiadów, ale także dla dzieci, które nie wiedziały, czym jest normalne życie, bez ostrzału, ciągłego ukrywania się i cierpienia ${ }^{81}$. Według danych UNICEF podczas wojny snajperzy strzelali do $40 \%$ dzieci zamieszkujących Sarajewo, 51\% z nich widziało zwłoki, $19 \%$ było świadkami masakry, $73 \%$ przeżyło ostrzał swego domu, $81 \%$ znalazło się w sytuacji, gdy bało się śmierci, a aż 89\% żyło w podziemnych schronach lub piwnicach $^{82}$.

W lipcu 1992 r. Z. Filipović pisała:

To jest moje życie! (...) Uczennicy, która nie ma już szkoły, żadnych radości i żadnych szkolnych przeżyć. Dziecka, które już się nie bawi, żyje bez przyjaciół, bez słońca, bez ptaków, bez przyrody, bez owoców, bez czekolady i cukierków, tylko z odrobiną mleka w proszku. Dziecka, które - mówiąc krótko - nie ma dzieciństwa. Dziecka wojny. Teraz naprawdę widzę, że żyję w wojnie, że jestem świadkiem wstrętnej, odrażającej wojny. Ja i tysiące innych dzieci w tym mieście, niszczonym, płaczącym, lamentującym, szukającym pomocy, która nie przyjdzie ${ }^{83}$.

Wiele dzieci było rannych lub ginęło w wyniku ostrzału artyleryjskiego czy snajperskiego. Część z nich pozostawała kalekami lub trafiała do sierocińców. Niektóre z nich miały więcej szczęścia i były wywożone z Sarajewa, czasami poza granice $\mathrm{BiH}$, w czym często pomagały relacje medialne i zainteresowanie ich problemem wśród przedstawicieli Zachodu. Tak było np. z pięcioletnią Irmą Hadžimuratović, która została ciężko ranna w wyniku ataku moździerzowego i po spektakularnej akcji dyplomatycznej władz Wielkiej Brytanii przetransportowano ją w 1993 r. z bośniackiej stolicy do Londynu ${ }^{84}$.

${ }^{81}$ Ich doświadczeniom poświęcony jest np. zbiór wspomnień, vide: J. Halilović, Djetinjstvo u ratu. Sarajevo 1992-1995., Sarajevo 2012 (polska wersja: J. Halilović, Wojenne dzieciństwo, Sarajewo 2018). Zawiera on aż 1030 krótkich wpisów (do 160 znaków) osób, które były dziećmi w czasie oblężenia. Natomiast w 2017 r. powstało w Sarajewie Muzeum Wojennego Dzieciństwa. Więcej o tych inicjatywach: M. ŚLAwsKA, Archiwizacja i muzealizacja pamięci pokoleniowej. Jasminko Halilović Djetinjstvo u ratu. Sarajevo 1992-1995. oraz Muzej ratnog djetinjstva, „Acta Universitatis Wratislaviensis. Slavica Wratislaviensia" 2021, t. 173, s. 511-521.

82 A. Werner, M. Ko€odziejCZy K, op. cit., s. 62.

83 Z. Filipović, op. cit., s. 51.

${ }^{84}$ Niestety dziewczynka zmarła w 1995 r. Vide: B. Simms, Unfinest Hour. Britain and the Destruction of Bosnia, London 2002, s. 36-37. Jednak dzięki medialnemu nagłośnieniu losu Irmy udało się ewakuować z Sarajewa wiele innych rannych i chorych dzieci. 
Na dramatyczny los Sarajewa wielokrotnie zwracał uwagę Tadeusz Mazowiecki, specjalny wysłannik Komisji Praw Człowieka ONZ do byłej Jugosławii. Osobiście sprawdzał w czasie swej misji, jak wyglądała sytuacja w poszczególnych częściach dawnej federacji Słowian południowych, w tym także w Sarajewie. W jednym z jego raportów z listopada 1992 r. czytamy:

Ostrzeliwanie domów mieszkalnych $\mathrm{i}$ biur, a także stałe zagrożenie strzałami snajperów powodują - poza zagrożeniem życia - powstawanie wielkich stresów. Zniszczenie przez obie strony konfliktu urządzeń publicznych zaopatrujących ludność w wodę, środki higieny i elektryczność spowodowało, że ludzie żyją w prymitywnych warunkach. (...) Wszystkie strony konfliktu są winne użycia wojsk przeciwko ludności cywilnej i przeciwko akcjom niesienia pomocy w Sarajewie. Nie można jednak pominąć faktu, że główna odpowiedzialność za taki stan rzeczy spoczywa na siłach serbskich, ponieważ one przyjęły taktykę oblężenia miasta ${ }^{85}$.

Natomiast w sierpniu 1994 r. Mazowiecki napisał:

Patrzyłem na cierpienie i heroiczną obronę tego miasta. (...) Poruszałem się opancerzonym transporterem i jedynie przez jego niewielkie okienka widziałem zniszczenia całych dzielnic, ostrzelane lub wypalone domy, wraki poprzewracanych tramwajów i samochodów, gdzieniegdzie szybko przebiegających ludzi. Od czasu do czasu przejeżdżało się przez dzielnice, w których odbywał się ruch, widać było pieszych, rowerzystów i ludzi popychających wózki z otrzymaną właśnie z rozdziału żywnością lub opałem. Wszędzie, gdzie tylko na trochę dłużej ustawał ostrzał, ludzie pojawiali się na ulicach. Po wielu miesiącach oblężenia, mimo lęku, nie mogli już dłużej wytrzymać w piwnicach i domach ${ }^{86}$.

Niestety bez echa pozostawały wielokrotne apele byłego premiera Polski, który wzywał do zdecydowanych działań społeczności międzynarodowej wobec konfliktów na południu Europy i tragicznych losów mieszkańców ogarniętych wojną państw, w tym także sarajewian ${ }^{87}$.

${ }^{85}$ Raport o sytuacji $w$ dziedzinie praw cztowieka na terytorium bytej Jugostawii, przygotowany przez Tadeusza Mazowieckiego, Specjalnego Sprawozdawce Komisji Praw Cztowieka na podstawie paragrafu 15 rezolucji Komisji 1992/S-1/1 z 14 VIII 1992 i decyzji Rady Spoteczno-Gospodarczej 1992/305 z 18 VIII 1992. Przedstawiony 17 XI 1992 r. przed Zgromadzeniem Ogólnym i opublikowany przez nie pod sygnatura A/47/666, [w:] Raporty Tadeusza Mazowieckiego z bytej Jugostawii, Poznań-Warszawa 1993, s. 78-79.

${ }^{86}$ T. Mazow Iecki, [Przedmowa], [w:] Z. Filipović, op. cit., s. 5-6.

${ }_{87}$ T. Mazowiecki podał się do dymisji po zdobyciu przez VRS Srebrenicy w lipcu $1995 \mathrm{r}$. 
Mieszkańcy Sarajewa codziennie musieli więc walczyć o życie, żywność, wodę, opał czy inne potrzebne artykuły. Niemal wszędzie mogli także zginąć. Jak zauważył J. Piekło:

Polec można od wybuchu granatu, od pocisku moździerza, strzału snajpera. Zginąć można biegnąc, siedząc w domu, czy nawet leżąc w szpitalnym łóżku. Umrzeć można z głodu, pragnienia, zimna czy choroby. A także z rozpaczy po śmierci najbliższych. Śmierć w Sarajewie ma wiele imion ${ }^{88}$.

Mimo tych trudnych warunków, w których musieli funkcjonować sarajewianie w latach 1992-1995, wielu z nich starało się jednak nie poddawać. Podejmowano np. różne działania w sferze kulturalnej, sportowej, rozrywkowej, jak chociażby wybory Miss Sarajewa w 1993 r. ${ }^{89}$ Formą oporu cywilów (zwłaszcza kobiet) było m.in. dbanie o swój wygląd. Jak zauważyła B. Demick:

Dla osoby z zewnątrz najbardziej zdumiewającą ze wszystkich form oporu było ogromne zaangażowanie, z jakim sarajewianki dbały o włosy, makijaż i higienę osobistą. Zagraniczni dziennikarze w wojskowych ciuchach, ubłoconych buciorach i nieuczesani od razu wyróżniali się w tłumie. Sarajewianki nosiły nienaganne fryzury i starannie wyprasowane ubrania. Korespondentów wojennych szybko przestawał dziwić widok eleganckich kobiet w futrach z norek, dźwigających drewno na opał albo stojących w kolejce po pomoc humanitarną ${ }^{90}$.

Symbolem takiej postawy sarajewianek było zrobione przez brytyjskiego fotoreportera, Toma Stoddarta, sławne zdjęcie kobiety idącej ulicą Sarajewa w 1995 r. Nazwano ją bośniacką Sophią Loren¹ . Fotografia została najpierw opublikowana w magazynie „Life”, a później w wielu innych znanych na całym świecie magazynach. Kobieta nazywała się Meliha Varešanović i o swej popularności na Zachodzie dowiedziała się dopiero po wielu latach. Jak sama później stwierdziła: „Nie nosiłam broni, ale walczyłam. (...) Moje zachowanie i sposób

88 J. PiekŁo, op. cit., s. 47.

89 Lider zespołu U2, Bono, stworzył w 1995 r. piosenkę Miss Sarajevo, nawiązując do wyborów Miss stolicy Bośni i Hercegowiny w 1993 r.

90 B. Demick, op. cit., s. 128.

9123 Years Later: Meliha Varesanovic, Woman who brought Glamour to War Zone, http://www. sarajevotimes.com/23-years-later-meliha-varesanovic-woman-who-brought-glamour-to-war-zone/ (dostęp: 25 II 2021). Zdjęcie to znalazło się na okładce wydanej jesienią 2020 r. książki tegoż fotografa, pt. Extraordinary Women. Images of Courage, Endurance and Defiance, do której wstęp napisała Angelina Jolie. 
ubierania się były moim sposobem na powiedzenie ostrzeliwującym: «Nigdy nie wygracie»!" 92 .

Kres cierpieniom dużej części sarajewian przyniósł koniec wojny i porozumienie w Dayton z listopada 1995 r. Ważnym elementem sporu w trakcie negocjacji pokojowych była kwestia przyszłości Sarajewa. Układ z Dayton przewidywał ostatecznie przejęcie przez rząd BiH także tej części stolicy, którą podczas oblężenia kontrolowali i zamieszkiwali Serbowie. Wówczas, w ciągu kilku miesięcy, nastąpił masowy exodus ludności serbskiej ${ }^{33}$. Kolejny raz zmieniła się struktura narodowościowa miasta.

W czasie trwającego trzy i pół roku oblężenia Sarajewa życie straciły tysiące jego mieszkańców, a dziesiątki tysięcy zostało rannych ${ }^{94}$. Wiele budynków mieszkalnych, jak i użyteczności publicznej, zostało uszkodzonych lub zniszczonych. Przedłużający się konflikt w $\mathrm{BiH}$, w tym losy sarajewian, budził zainteresowanie polityków i mediów z całego świata. Szczególną uwagę przykuwały bardzo dramatyczne wydarzenia z oblężenia Sarajewa, jak np. masakry, w których ginęło kilkadziesiąt osób. Czasami walczące strony, w tym słabsza - tj. Muzułmanie - starały się wykorzystać różne incydenty, korzystając z tzw. efektu CNN, by wpłynąć na działania społeczności międzynarodowej. Stolica $\mathrm{BiH}$, czasami przesadnie, była wówczas porównywana do ogarniętych konfliktami Bejrutu czy Irlandii Północnej, do zniszczonej Warszawy po powstaniu warszawskim czy też do Leningradu w czasie jego oblężenia podczas II wojny światowej.

Sarajewo nie było już pomostem między Wschodem i Zachodem, lecz przykładem tragicznych konsekwencji braku porozumienia pomiędzy przedstawicielami różnych narodów. Jednak trzeba pamiętać, że podczas oblężenia miasta, częściowo podzielonego, po stronie obleganych znalazły się także tysiące Serbów, Chorwatów czy osób określających się jako Jugosłowianie, którzy - jak stanowiący przed wojną niemal połowę mieszkańców Sarajewa bośniaccy Muzułmanie - również byli narażeni na ostrzał ze strony wojsk gen. Mladicia czy inne skutki częściowego odcięcia miasta od świata. Wojna zmieniała radykalnie życie setek tysięcy sarajewian, którzy przez wiele miesięcy - każdego dnia

92 International Women's Day 2021, https://iconicimages.net/news/international-womens-day-2021/ (dostęp: 8 III 2021).

93 S. Soch ACKI, Bośnia i Hercegowina 1995-2012. Studium politologiczne, Toruń 2015, s. 42; K. Krysieniel, op. cit., s. 179.

${ }_{94}$ Więcej o stratach i zniszczeniach w Sarajewie, vide: K. Krysieniel, op. cit., s. 178-179; R.J. Donia, op. cit., s. 364-365. 
- musieli toczyć batalię o przeżycie swoje, jak i swoich bliskich. Wyzwaniem było np. zdobycie żywności, wody, leków, a zimą opału, czy uzyskanie informacji o tym, kto z bliskich czy znajomych zginął, został ranny lub wyjechał.

Ważną rolę w przetrwaniu miasta odegrały dostawy pomocy humanitarnej, zwłaszcza przez lotnisko sarajewskie. Jednak wielokrotnie strony konfliktu blokowały konwoje przybywające do stolicy BiH drogą lądową, a ze względów bezpieczeństwa most powietrzny wielokrotnie przerywano, co oznaczało szybkie wyczerpanie się zapasów w magazynach ONZ i kłopoty z zaopatrzeniem dla tysięcy sarajewian. Problemem były również ograniczenia w dostępie do np. gazu czy elektryczności. Oznaczało to konieczność improwizacji i prób radzenia sobie mimo powtarzanego jak mantra hasła „Niczego nie ma”.

Mieszkańcy Sarajewa byli narażeni na ostrzał artyleryjski i snajperski. Często celem ataków stawali się ludzie stojący w kolejce po wodę czy żywność. Niewiele zmieniało w codziennym funkcjonowaniu sarajewian zawieranie dziesiątków kolejnych rozejmów (które czasami - już w momencie wejścia w życie - były łamane) czy też uznanie przez ONZ od połowy 1993 r. bośniackiej stolicy, obok pięciu innych miast, za tzw. strefę bezpieczeństwa.

Oczywiście w tych trudnych warunkach kwitł czarny rynek i możliwość załatwienia niemal wszystkiego, łącznie z oficjalnym wyjazdem z Sarajewa, gdy ktoś posiadał odpowiednią kwotę w dewizach lub znał właściwie osoby.

Sarajewianie podczas wojny marzyli o „normalnym życiu”, o wyjeździe chociaż na kilka dni nad morze czy o dostępie do owoców lub prawdziwego mleka (zamiast tego w proszku z dostaw). Codziennością stawało się ukrywanie w piwnicach czy schronach podczas ostrzału, poruszanie się biegiem po niebezpiecznych częściach miasta czy wycinanie drzew lub niszczenie książek, by mieć czym ogrzać pokój w czasie zimy. Rosło także pokolenie dzieci, które nie miały żadnych wspomnień z normalnego życia.

Jednak pomimo tych warunków wielu sarajewian starało się żyć niezależnie od trudności i zagrożeń związanych z oblężeniem. Cieszyły narodziny dziecka czy rozegrany mecz piłki nożnej, organizowano najróżniejsze imprezy kulturalne. Formą oporu cywilnego była nawet kwestia ubioru czy malowania się kobiet. Czekano na zakończenie wojny i powrót do życia, które pamiętano sprzed $1992 \mathrm{r}$.

Dzięki układowi z Dayton skończył się dramat setek tysięcy mieszkańców $\mathrm{BiH}$, w tym większości sarajewian. Po wielomiesięcznym oblężeniu cieszyły 
rzeczy, które nam wydają się normalne w życiu codziennym. Jak mówiła na początku 1996 r. lekarka Kasem Telalagić:

Nie wiem, czy potrafisz zrozumieć, co to za radość, kiedy możesz odkręcić kran i umyć naczynia, nastawić pralkę, patrzeć przez okno na wzgórza i widzieć te wszystkie światła... Z początku, kiedy ucichły działa, budziłam się w nocy i nie mogłam uwierzyć, że nie słychać strzałów. Teraz przesypiam całą noc, ani razu się nie budząc $c^{95}$.

Rozpoczynał się trudny proces odbudowy miasta i relacji pomiędzy jego mieszkańcami. Niestety nie była to ostatnia odsłona konfliktów na gruzach federacji jugosłowiańskiej. Za kilka lat bałkańska beczka prochu ponownie eksploduje w Kosowie...

Warunki życia w Sarajewie w latach 1992-1995 to zagadnienie obszerne i wymagające badań zakrojonych na szerszą skalę. Niniejszy artykuł należy traktować jako próbę zwrócenia uwagi na tę kwestię a zarazem jako zapowiedź dalszych publikacji przybliżających egzystencję ludności cywilnej podczas tego bałkańskiego konfliktu.

\section{BIBLIOGRAFIA}

\section{Źródła drukowane}

Akashi Y., In the Valley Between War and Peace - Personalities I Met, Belgrade 2011.

Bosna i Hercegovina u vreme raspada SFRJ 1990-1992. Tematska zbirka dokumenata, prir.

K. Nikolić, Beograd 2011.

Demick B., Woblężeniu. Życie pod ostrzatem na sarajewskiej ulicy, Wołowiec 2014.

Filipović Z., Dziennik Zlaty, przedm. T. Mazowiecki, Warszawa 1994.

Ghesquière H., Sarajewo. Rany są nadal zbyt gtębokie, Kraków 2017.

Halilbegovich N., My Childhood Under Fire. A Sarajevo Diary, Toronto 2006.

Izetbegović A., Inescapable Questions. Autobiographical Notes, Leicester 2003.

Pejanović M., Through Bosnian Eyes. The Political Memoir of the Bosnian Serb, introd. by R.J. Donia, West Lafayette 2004.

Prosecutor v. Radovan Karadžić. Public Redacted Version of Judgement Issued on 24 March 2016, Case No.: IT-95-5/18-T, International Tribunal for the Prosecution of Persons

${ }^{9}$ Cit.per: B. Demick, op. cit., s. 198. 
Responsible for Serious Violations of International Humanitarian Law Committed in the Territory of the former Yugoslavia since 1991, https://www.icty.org/x/cases/ karadzic/tjug/en/160324_judgement.pdf(dostęp: 20 I 2021).

Raporty Tadeusza Mazowieckiego z bytej Jugostawii, Poznań-Warszawa 1993.

Vuković Ž., Sarajewo - miasto atrapa, Toruń 2002.

Vuković Ž., Zabijanie Sarajewa. Napisane w Sarajewie i $w$ Belgradzie od maja do końca grudnia 1992 roku, Toruń 2000.

Warszawski D. [Gebert K.], Obrona poczty sarajewskiej, Warszawa 1995.

Werner A., Kołodziejczyk M., Mecz to pretekst. Futbol, wojna, polityka, Kraków 2020.

\section{Prasa}

„Gazeta Wyborcza” 1992-1996, 2007.

„Polityka” 2012.

\section{Opracowania}

Andreas P., Blue Helmets and Black Markets. The Business of Survival in the Siege of Sarajevo, Ithaca-London 2008.

Balkan Battlegrounds: A Military History of the Yugoslav Conflict, 1990-1995, vol. 1, Washington 2002.

Batkany. Bośnia i Hercegovina, Serbia, Kosowo, Macedonia, Albania. Przewodnik, Kraków 2009.

Begić K.I., Bosna i Hercegovina. Od Vanceove misije do Daytonskog sporazuma (1991. -1996.), Sarajevo 1997.

Bogdanović B., Obrona miasta. List do sarajewskich przyjaciót, „Krasnogruda” 1997, nr 6, s. 99-101.

Bogdanović B., Rytualne zabijanie miasta, „Krasnogruda” 1997, nr 6, s. 27-32.

Brock P., Media Cleansing: Dirty Reporting. Journalism and Tragedy in Yugoslavia, foreword by D. Binder, Los Angeles 2006.

Bujwid-Kurek E., Rola Alii Izetbegovicia w ksztattowaniu muzutmańskiej wspólnoty narodowej Bośni i Hercegowiny, „Slavia Meridionalis” 2011, nr 11, s. 175-190.

Ciechanowski G., Operacje pokojowe ONZ wXX wieku, Toruń 2013.

Donia R.J., Sarajevo: biografija grada, Sarajevo 2006.

Garton Ash T., Historia na gorąco. Eseje i reportaże z Europy lat 90., Kraków 2000. 
Gucka A., Wieloetniczność Sarajewa - rys historyczny, [w:] Batkany Zachodnie między przesztością a przysztością, red. P. Chmielewski, S.L. Szczesio, Łódź 2013, s. 369-380.

Halilović J., Wojenne dzieciństwo, Sarajewo 2018.

Hoare M.A., Wojna jugostowiańska, [w:] Polityka Europy Środkowej i Potudniowo-Wschodniej po 1989 roku, red. S.P. Ramet, Warszawa 2012, s. 139-164.

Ibrahimagić O., Državno-pravni razvitak Bosne i Hercegovine = Constitutional development of Bosnia and Hercegovina, Sarajevo 1998.

Jones Ch., François Mitterrand's Visit to Sarajevo, 28 June 1992, „Diplomacy and Statecraft" 2017, vol. 28, no. 2, s. 296-319.

King C.S., The Siege of Sarajevo, 1992-1995, [w:] Block by Block: The Challenges of Urban Operations, eds W.G. Robertson, L.A. Yates, Fort Leavenworth [2003], s. 235-290.

Korzeniewska-Wiszniewska M., Serbia pod rządami Slobodana Miloševicia. Serbska polityka wobec rozpadu Jugostawii w latach dziewięćdziesiątych XX wieku, Kraków 2008.

Korzeniewska-Wiszniewska M., Serbowie jako mniejszość w warunkach transformacji politycznej w państwach bytej Jugostawii 1995-2016, Kraków 2017.

Krysieniel K., W cieniu Dayton. Bośnia i Hercegowina między etnokracja i demokracja konsocjonalna, Warszawa 2012.

Krzak A., Charakterystyka dziatań militarnych w Bośni w latach 1992-1993, [w:] Bośnia i Hercegowina 15 latpo Dayton. Przesztość - teraźniejszość - perspektywy. Studia i szkice, red. P. Chmielewski, S.L. Szczesio, Łódź 2011, s. 25-49.

Lučić I., Bosna i Hercegovina od prvib izbora do medunarodnog priznanja, „Časopis za suvremenu povijest" 2008, br. 1, s. 107-140.

Lučić I., Uzroci rata. Bosna i Hercegovina od 1980. do 1992. godine, Zagreb 2013.

Maček I., Sarajevo Under Siege. Anthropology in Wartime, Philadelphia 2009.

Mikołajczyk M., François Mitterrand wobec rozpadu Jugostawii w latach 1991-1995, „Balcanica Posnaniensia. Acta et studia" 2013, [t.] 20, s. 195-216.

Piekło J., Sarajewo: agonia nadziei, [w:] Wezet batkański, red. J. Piekło, S. Wilkanowicz, Kraków 1999, s. 39-53.

Plaster J.L., The History of Sniping and Sharpshooting, Boulder 2008.

Pomykalscy B. i P., Jugostawia. Rozsypana uktadanka, Gliwice 2017.

Preez du Bezdrob A.M., Sarajevo Roses. War Memoir of a Peacekeeper, Cape Town 2004.

Rawski T., Boszniacki nacjonalizim. Strategia budowania narodu po 1995 r., Warszawa 2019.

Simms B., Unfinest Hour. Britain and the Destruction of Bosnia, London 2002.

Skrzeszewska M., „Kap moje krvi poteče i Bosna ne presuši” - pamięć o oblężeniu Sarajewa, „Studenckie Zeszyty Naukowe Instytutu Filologii Słowiańskiej UJ” 2014, nr 2(6), s. $125-139$.

Sochacki S., Bośnia i Hercegowina 1995-2012. Studium politologiczne, Toruń 2015. 
Szczesio S.L., Droga ku wojnie - sytuacja w Bośni i Hercegowinie w latach 1990-1992, [w:] Batkany w XX i XXI wieku. Historia - polityka - kultura. Materiaty z konferencji „Poznać Batkany”. Toruń, 29 maja 2009 roku, red. H. Stys, S. Sochacki, Toruń 2009, s. 23-41.

Szczesio S.L., Rola sit pokojowych ONZ w wojnie w Bośni i Hercegowinie (1992-1995) - wybrane zagadnienia, „Acta Universitatis Lodziensis. Folia Historica” 2018, t. 101, s. 191-207.

Ślawska M., Archiwizacja i muzealizacja pamięci pokoleniowej. Jasminko Halilović Djetinjstvo u ratu. Sarajevo 1992-1995. oraz Muzej ratnog djetinjstva, „Acta Universitatis Wratislaviensis. Slavica Wratislaviensia” 2021, t. 173, s. 511-521.

Ślawska M., Jak opowiedzieć śmierć? Oblężenie Sarajewa w relacjach dziewcząt, „Acta Universitatis Wratislaviensis. Slavica Wratislaviensia” 2019, t. 170, s. 41-51.

Uchodźcy świata 2000. 50 lat pomocy humanitarnej, Warszawa 2000.

Vulliamy E., Wojna umarta, niech żyje wojna. Bośniackie rozrachunki, Wołowiec 2016.

Waldenberg M., Rozbicie Jugostawii od separacji Stowenii do wojny kosowskiej, Warszawa 2003.

War in the Balkans. An Encyclopedic History from the Fall of the Ottoman Empire to the Breakup of Yugoslavia, ed. R.C. Hall, Santa Barbara 2014.

Warszawski D. [Gebert K.], Sarajewo, „Krasnogruda” 1997, nr 6, s. 102-111.

Wybranowski D., Między niepodlegtością a dezintegracją. Bośnia i Hercegowina w XX $i$ XXI wieku, Szczecin 2011.

Wybranowski D., Początki ipierwsze lata dziatalności Armii Republiki Bośni i Hercegowiny, [w:] Bośnia i Hercegowina 15 lat po Dayton. Przesztość - teraźniejszość - perspektywy. Studia i szkice, red. P. Chmielewski i S.L. Szczesio, Łódź 2011, s. 153-178.

Zacharias M.J., Komunizm, federacja, nacjonalizmy. System wtadzy w Jugostawii 19431991. Powstanie, przeksztatcenia, rozktad, Warszawa 2004.

\section{Netografia}

23 Years Later: Meliha Varesanovic, Woman who brought Glamour to War Zone, http:// www.sarajevotimes.com/23-years-later-meliha-varesanovic-woman-who-broughtglamour-to-war-zone/ (dostęp: 25 II 2021).

International Women's Day 2021, https://iconicimages.net/news/international-womens-day-2021/ (dostęp: 8 III 2021).

Sarajevo u periodu 1945.-1991. godina, https://www.sarajevo.ba/en/article/1222/sarajevo-u-periodu-1945-1991-godina (dostęp: 12 II 2021).

http://www.nadjapeace.com (dostęp: 22 II 2021). 


\section{Sławomir Lucjan Szczesio}

\section{EVERYDAY LIFE IN BESIEGED SARAJEVO (1992-1995)}

Summary. Sarajevo is the capital of Bosnia and Herzegovina, sometimes called the European Jerusalem. For many centuries, this city was a multi-ethnic society with a traditions of diversity and religious tolerance, between the East and West. Muslims, Serbs, Croats and other nationalities lived there peacefully, side by side. On the eve of war in 1992, about $50 \%$ of the city's population was non-Muslim and many marriages were religiously and ethnically intermixed.

After the referendum on independence of Bosnia and Herzegovina, the representatives of the three major nations of this republic couldn't reach an agreement about the future. In April 1992, tensions in Bosnia and Herzegovina exploded into a bloody war. Sarajevo became a symbol of ethnic conflict and humanitarian intervention. The city was divided into two parts. A large part of Sarajevo, which was controlled by the government of Bosnia and Herzegovina, had been under siege by the Army of the Republika Srpska.

During the three-and-a-half-year siege of Sarajevo, civilians were attacked by snipers and artillery shells in their homes, and while buying food in marketplaces, searching for water, and walking down the street. It was like Russian roulette. Food and water shortages had become a part of everyday life in Sarajevo. The supplies of electricity and gas were irregular. Airlifts and humanitarian relief (mainly from UNHCR) helped keep the city from starving. Despite months of siege, thousands of civilians dead, and the lives of each Sarajevan radically changed, the people of Sarajevo refused to yield to their aggressors.

Keywords: disintegration of Yugoslavia, war in Bosnia and Herzegovina, Sarajevo, siege of Sarajevo, everyday life 